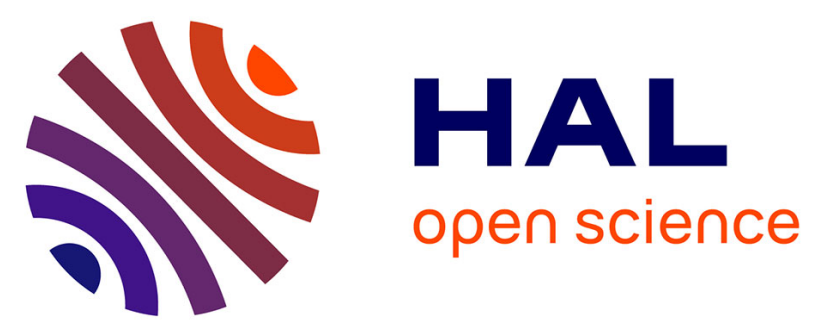

\title{
Access to Highly Enantioenriched Donepezil-like 1,4-Dihydropyridines as Promising Anti-Alzheimer Prodrug Candidates via Enantioselective Tsuji Allylation and Organocatalytic Aza-Ene-Type Domino Reactions \\ Mihaela-Liliana Ţînţaş, Rabah Azzouz, Ludovic Peauger, Vincent Gembus, Emilie Petit, Laëtitia Bailly, Cyril Papamicaël, Vincent Levacher
}

\section{To cite this version:}

Mihaela-Liliana Ţînţaş, Rabah Azzouz, Ludovic Peauger, Vincent Gembus, Emilie Petit, et al.. Access to Highly Enantioenriched Donepezil-like 1,4-Dihydropyridines as Promising Anti-Alzheimer Prodrug Candidates via Enantioselective Tsuji Allylation and Organocatalytic Aza-Ene-Type Domino Reactions. Journal of Organic Chemistry, 2018, 83 (17), pp.10231-10240. 10.1021/acs.joc.8b01442 . hal03134345

\author{
HAL Id: hal-03134345 \\ https://hal.science/hal-03134345
}

Submitted on 8 Feb 2021

HAL is a multi-disciplinary open access archive for the deposit and dissemination of scientific research documents, whether they are published or not. The documents may come from teaching and research institutions in France or abroad, or from public or private research centers.
L'archive ouverte pluridisciplinaire HAL, est destinée au dépôt et à la diffusion de documents scientifiques de niveau recherche, publiés ou non, émanant des établissements d'enseignement et de recherche français ou étrangers, des laboratoires publics ou privés. 


\section{Article}

Subscriber access provided by University of Winnipeg Library

Access to highly enantioenriched donepezil-like 1,4-dihydropyridines as promising anti-Alzheimer prodrug candidates via enantioselective Tsuji allylation and organocatalytic aza-ene-type domino reactions

Mihaela-Liliana TINTAS, Rabah Azzouz, Ludovic Peauger, Vincent GEMBUS, Emilie Petit, Laetitia Bailly, Cyril Papamicaël, and Vincent Levacher

J. Org. Chem., Just Accepted Manuscript • DOI: 10.1021/acs.joc.8b01442 • Publication Date (Web): 13 Jul 2018

Downloaded from http://pubs.acs.org on July 14, 2018

\section{Just Accepted}

"Just Accepted" manuscripts have been peer-reviewed and accepted for publication. They are posted online prior to technical editing, formatting for publication and author proofing. The American Chemical Society provides "Just Accepted" as a service to the research community to expedite the dissemination of scientific material as soon as possible after acceptance. "Just Accepted" manuscripts appear in full in PDF format accompanied by an HTML abstract. "Just Accepted" manuscripts have been fully peer reviewed, but should not be considered the official version of record. They are citable by the Digital Object Identifier (DOI®). "Just Accepted" is an optional service offered to authors. Therefore, the "Just Accepted" Web site may not include all articles that will be published in the journal. After a manuscript is technically edited and formatted, it will be removed from the "Just Accepted" Web site and published as an ASAP article. Note that technical editing may introduce minor changes to the manuscript text and/or graphics which could affect content, and all legal disclaimers and ethical guidelines that apply to the journal pertain. ACS cannot be held responsible for errors or consequences arising from the use of information contained in these "Just Accepted" manuscripts. 


\section{Access to highly enantioenriched donepezil-like 1,4- dihydropyridines as promising anti-Alzheimer prodrug candidates via enantioselective Tsuji allylation and organocatalytic aza-ene- type domino reactions}

Mihaela-Liliana Ţînţaş, ${ }^{\dagger}$ Rabah Azzouz, ${ }^{\#}$ Ludovic Peauger, ${ }^{\#}$ Vincent Gembus, ${ }^{*}, \#$ Emilie Petit, ${ }^{\dagger}$ Laetitia Bailly, ${ }^{\dagger}$ Cyril Papamicaël, ${ }^{\dagger}$ and Vincent Levacher ${ }^{*, \dagger}$

†Normandie Université, UNIROUEN, INSA Rouen, CNRS, COBRA, 76000 Rouen, France.

\# VFP Therapies, R\&D, 1 rue Tesnière, 76130 Mont Saint-Aignan, France.

Table of Content Graphic :
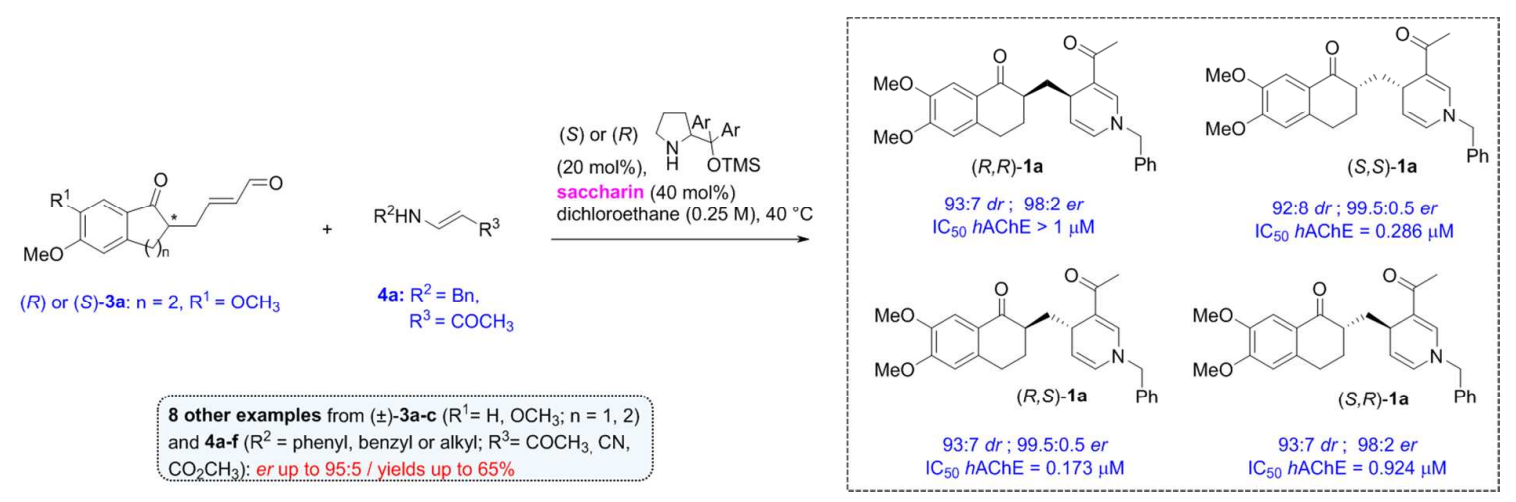

\section{ABSTRACT}

This work aims at exploiting both the enantioselective Tsuji allylation of allyl carbonate 6 and an organocatalytic aza-ene-type domino reaction between enal $3 \mathbf{a}$ and $\beta$-enaminone $4 \mathbf{a}$ to develop a straightforward access to all of the four possible stereoisomers of a donepezil-like 1,4-dihydropyridine 1a (er up to 99.5:0.5; overall yield up 64\%); an anti-Alzheimer prodrug candidate. This strategy was extended to the preparation of other enantioenriched 1,4- 
dihydropyridines 1b-i (8 examples), highlighting its potential in the development of these chiral AChE inhibitors.

\section{INTRODUCTION}

1,4-dihydropyridine nucleus (DHPs) is viewed as a privileged scaffold due to its virtue for selectively modulating diverse receptors, channels and enzymes, when conveniently substituted. ${ }^{1}$ Particularly, these compounds are closely related to the NADH $\left(\leftrightarrows \mathrm{NAD}^{+}\right)$ coenzyme by mimicking its oxido-reductive activity. Bodor et al. took advantage of these redox properties to develop a brain targeting chemical delivery system (CDS) based on the 1,4-dihydrotrigonelline $\leftrightarrow$ trigonelline system. ${ }^{2,3}$ For several years, our group has been interested in this approach, ${ }^{4}$ and as part of our Alzheimer's disease research program, we have recently described the design and preparation of several prodrugs of donepezil analogues based on a bio-oxidisable strategy and tested their inhibitory activities against human acetyl cholinesterase (hAChE)..$^{4 g, f}$ In most of cases, the designed drugs displayed high inhibitory activities although, as expected, the corresponding prodrugs were inactive. However, during these research investigations, we highlighted that some of the obtained 1,4dihydropyridine (1,4-DHP) derivatives showed nonetheless a significant inhibitory activity. One of the most active 1,4-DHP, the compound 1a, displayed a three-digit nanomolar activity against $h \mathrm{AChE}\left(\right.$ Scheme $\left.1 \mathrm{a}, \mathrm{IC}_{50}=0.415 \mu \mathrm{M}\right)$. The tested 1,4-DHPs are issued from a nonstereocontrolled synthesis (Scheme 1a), affording a mixture of the all four possible stereomers due to the presence of two chiral carbons at both tetralone and 1,4dihydropyridine rings. Obviously, it is well known that enantiomers of a chiral drug may display marked differences in their pharmacological behavior arising from strong differences in their interactions with enzymes, proteins, receptors and other chiral molecules in living systems. ${ }^{5}$ Keeping this in mind, we turned our interest toward the investigation of the structure-activity relationship of each stereoisomers A-D of 1a with $h A C h E$. To address this issue, all the four stereoisomers A-D were isolated by super critical fluid chromatography on 
a chiral stationary phase. An in vitro evaluation of the so-obtained four stereoisomers A-D highlighted a striking disparity of the biological activity (i.e. $I C_{50}$, Scheme $\left.1 a\right){ }^{4 f}$ To complete our investigation, it was necessary to attribute the absolute configuration at both stereogenic centers of each stereoisomer A-D and we naturally turned our attention to enantioselective synthesis of the target chiral 1,4-DHPs 1a. Although the racemic preparation of 4-substituted $1,4-\mathrm{DHPs}$ is well documented in the literature ${ }^{6}$ only a few catalytic asymmetric approaches are reported. These are either based on the organocatalytic asymmetric construction of 1,4$\mathrm{DHPs}^{7}$ or more recently on regioselective organocatalytic 1,4 -addition of enolate derivatives to $\mathrm{N}$-alkyl pryridinium salts. ${ }^{7 f-g}$ Taking the structure of our target 1a into account, the organocatalytic aza-ene-type cascade reaction described by Kanger et al. appeared to be the most appropriate approach to provide access to highly enantioenriched donepezil-like 1,4-dihydropyridine prodrugs. ${ }^{7 e}$ It involves an iminium activation of $\alpha, \beta$-unsaturated aldehyde by means of Jørgensen-Hayashi catalyst in the presence of $\beta$-enaminones or $\beta$-enamino esters to furnish the desired 1,4-DHPs in good yields (45-86\%) along with moderate to very good enantioselectivities (62-96\%). According to this approach, the enantioenriched enal 3a precursor would be accessible by an enantioselective Tsuji allylation ${ }^{8} /$ cross-metathesis $^{2}$ sequence from $\alpha$-tetralone $\mathbf{2 a}$, whereas the starting enaminone $4 \mathbf{a}$ would be prepared by condensation of benzylamine with trans-methoxy-3-buten-2-one (Scheme 1b). Herein, we report a straightforward access to donepezil-like 1,4-dihydropyridine prodrugs 1a-i and an asymmetric approach allowing the preparation of each of the four possible stereoisomers via an aminocatalyzed cyclisation as the key step.

Scheme 1. (a) Previous non-stereocontrolled route to donepezil-like 1,4-dihydropyridine prodrug 1a; (b) Asymmetric approach developed in this work 
a) Previous work: ${ }^{4 f}$<smiles>COc1cc2c(cc1OC)C(=O)/C(=C/c1ccncc1Br)CC2</smiles><smiles>COc1cc2c(cc1OC)C(=O)C(CC1C=CN(Cc3ccccc3)C=C1C(C)=O)CC2</smiles>

Chiral SFC separation diastereomer $\mathrm{A}, \mathrm{IC}_{50} h$-AChE: $>1 \mu \mathrm{M}$ diastereomer $\mathrm{B}, \mathrm{IC}_{50} h$-AChE: $0.286 \mu \mathrm{M}$ diastereomer C, IC ${ }_{50} h$-AChE: $0.173 \mu \mathrm{M}$ diastereomer $\mathrm{D}, \mathrm{IC}_{50} h$-AChE: $0.924 \mu \mathrm{M}$

Donepezil-like AChE inhibitor bio-oxidisable prodrug 1a $\mathrm{IC}_{50} h$-AChE: $0.415 \mu \mathrm{M}$

b) Present work:

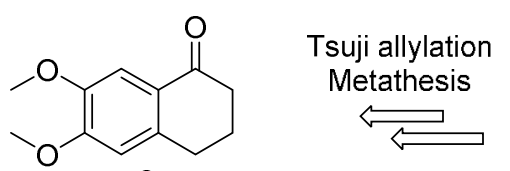
2a

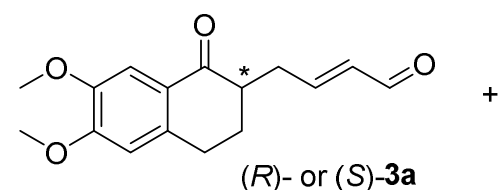

Enantioselective Aminocatalysis

\section{RESULTS AND DISCUSSION}

First of all, we set out to explore the scope of this new straightforward route to prepare donepezil-like 1,4-dihydropyridine prodrugs 1 a-i in a non-stereocontrolled fashion. ${ }^{6}$ To this end, the required enals $( \pm)$-3a-c were prepared in a two-step sequence by allylation of arylketones $\mathbf{2 a - c ^ { 9 }}$ affording the corresponding $\alpha$-allylated arylketones ( \pm )-5a-c in $46-68 \%$ yields followed by cross-metathesis in the presence of an excess of crotonaldehyde (Scheme 2). Thus, Hoveyda-Grubbs $2^{\text {nd }}$ generation catalyst $(2.5 \mathrm{~mol} \%)$ in dichloromethane at reflux overnight were used to afford the expected racemic enals ( \pm )-3a-c in good to excellent yields $(83-91 \%)$.

\section{Scheme 2. Preparation of enals ( \pm )-3a-c}




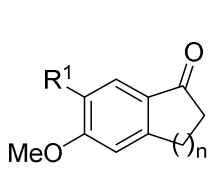

2a: $\mathrm{R}^{1}=\mathrm{CH}_{3} \mathrm{O}, \mathrm{n}=2$

2b: $\mathrm{R}^{1}=\mathrm{H}, \mathrm{n}=2$

2c: $\mathrm{R}^{1}=\mathrm{CH}_{3} \mathrm{O}, \mathrm{n}=1$

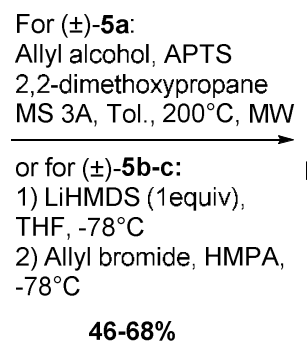

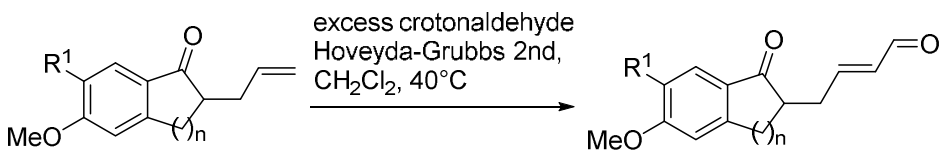

$( \pm)-5 a-c$

$83-91 \%$

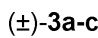
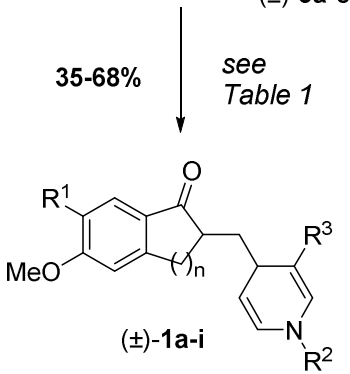

Following the reaction conditions described by Renaud et al., ${ }^{6 g}$ the desired dihydropyridine 1a was obtained by reacting enal $( \pm)$-3a with enaminone $4 a$ in the presence of scandium triflate as a catalyst in dichloromethane (Table 1, entry 1). Besides the preparation of the target $\mathbf{1 a}$, a representative panel of $1,4-\mathrm{DHPs} \mathbf{1} \mathbf{b}-\mathbf{g}$ was also prepared by reacting various enamine derivatives $4 \mathbf{a}-\mathbf{f}$ with enals $( \pm)$-3a-c. Except $\beta$-enamino nitrile $\mathbf{4 f}$ which failed to react (entries 9-10), all other 1,4-DHPs 1a-g were obtained in fair to good yields (up to 68\%) after purification by flash chromatography (Entries 1-8). Compared to our previously reported synthesis depicted in scheme $1 \mathrm{a},{ }^{4 \mathrm{f}}$ this new route provides a more convergent and direct access to 3,4-disubstitited 1,4-DHPs with fair overall yields.

Table 1. Preparation of $( \pm)-1,4-D H P s ~ 1 a-i^{a}$

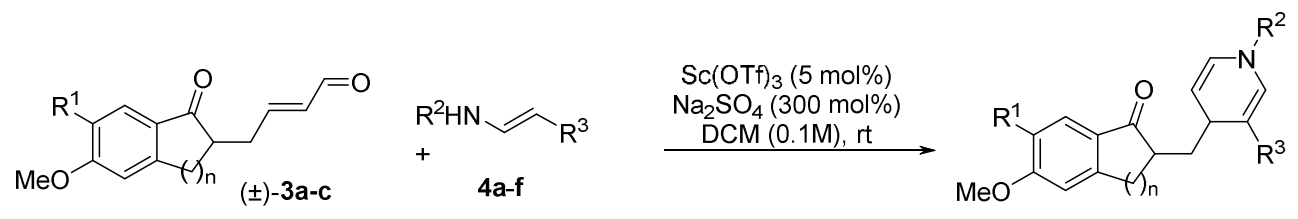

(士)-1a-i

\begin{tabular}{|c|c|c|c|c|c|c|c|c|}
\hline Entry & $( \pm)-3$ & $\mathrm{R}^{1}$ & $\mathrm{n}$ & 4 & $\mathrm{R}^{2}$ & $\mathrm{R}^{3}$ & Cpd & Yield (\%) \\
\hline 1 & $3 a$ & $\mathrm{CH}_{3} \mathrm{O}$ & 2 & $4 a$ & benzyl & $\mathrm{C}(\mathrm{O}) \mathrm{CH}_{3}$ & $1 a$ & 62 \\
\hline 2 & $3 b$ & $\mathrm{H}$ & 2 & $4 a$ & benzyl & $\mathrm{C}(\mathrm{O}) \mathrm{CH}_{3}$ & $1 b$ & 35 \\
\hline 3 & $3 b$ & $\mathrm{H}$ & 2 & $4 b$ & (2'-methyl)-benzyl & $\mathrm{C}(\mathrm{O}) \mathrm{CH}_{3}$ & 1c & 59 \\
\hline 4 & $3 b$ & $\mathrm{H}$ & 2 & $4 c$ & phenyl & $\mathrm{C}(\mathrm{O}) \mathrm{CH}_{3}$ & 1d & 65 \\
\hline 6 & $3 b$ & $\mathrm{H}$ & 2 & $4 d$ & $n$-propyl & $\mathrm{C}(\mathrm{O}) \mathrm{CH}_{3}$ & $1 e$ & 45 \\
\hline 7 & $3 c$ & $\mathrm{CH}_{3} \mathrm{O}$ & 1 & $4 a$ & benzyl & $\mathrm{C}(\mathrm{O}) \mathrm{CH}_{3}$ & $1 f$ & 55 \\
\hline 8 & $3 c$ & $\mathrm{CH}_{3} \mathrm{O}$ & 1 & $4 e$ & (2'-methyl)-benzyl & $\mathrm{CO}_{2} \mathrm{CH}_{3}$ & $1 \mathrm{~g}$ & 68 \\
\hline 9 & $3 c$ & $\mathrm{CH}_{3} \mathrm{O}$ & 1 & $4 f$ & benzyl & $\mathrm{CN}$ & $1 \mathrm{~h}$ & $0^{b}$ \\
\hline
\end{tabular}




$$
\begin{aligned}
& \begin{array}{lllllllll}
10 & 3 \mathbf{b} & \mathrm{H} & 2 & \mathbf{4 f} & \text { benzyl } & \mathrm{CN} & \mathbf{1 i} & 0^{b}
\end{array} \\
& { }^{a} \text { Reaction conditions: reactions performed at room temperature }\left(21^{\circ} \mathrm{C}\right) \text { under argon atmosphere with } \\
& \text { 3a-c (1.0 equiv), 4a-f (1.0 equiv), } \mathrm{Sc}(\mathrm{OTf})_{3}(5 \mathrm{~mol} \%), \mathrm{Na}_{2} \mathrm{SO}_{4} \text { (3.0 equiv.) in } \mathrm{CH}_{2} \mathrm{Cl}_{2}(0.1 \mathrm{M}) .{ }^{b} \text { No reaction }
\end{aligned}
$$

With enals ( \pm )-3a-c and enamines $4 a-f$ in hands, a general screening was performed to find the optimal reaction conditions for the enantioselective tandem aza-ene type reaction/ cyclization cascade as one-pot entry to enantiomerically enriched 1,4-DHPs 1a-i (Table 2). We first investigated the reaction between enal $( \pm)-3 a$ and enamine $4 a$ in the presence of MacMillan's catalyst I with trifluoroacetic acid (TFA) and $\mathrm{Na}_{2} \mathrm{SO}_{4}$ (Table 2, entry 1). ${ }^{10}$ After $16 \mathrm{~h}$ of reaction at room temperature, no trace of 1,4-DHP 1a could be observed by conducting a ${ }^{1} \mathrm{H}$ NMR analysis from the crude mixture. Similarly, the use of an admixture of catalyst II (20 mol\%) and benzoic acid (BA) (20 mol\%) in toluene at room temperature was disappointing since a very low catalytic activity was observed giving only traces of 1a (Table 2 , entry 2). A great stride forward was next reached by the use of the more bulky catalyst $\boldsymbol{S}$ III in combination with BA. Thus, the expected 1,4-DHP 1a was obtained in up to $30 \%$ yield and a good enantiomeric ratio (er= 88:12) for both diastereomers, however with a poor reproducibility (Table 2 , entry 3 ). Only traces of 1 a was obtained when decreasing the catalyst loading from 30 to $10 \mathrm{~mol} \%$ (Table 2, entries 4-5). Addition of $3 \AA$ molecular sieves as water scavengers provided reproducible yields up to $35 \%$ and a similar enantiomeric ratio (Table 2, entry 6). One may note that $4 \AA$ molecular sieves turned out to be even more efficient, furnishing $1 \mathrm{a}$ in up to $49 \%$ yield (Table 2, entry 7 ). To our delight, when mixing catalyst $S$-III with the more acidic saccharin in toluene at $40^{\circ} \mathrm{C}, 1,4-\mathrm{DHP} 1$ a was isolated in a satisfactory $60 \%$ yield after only $0.5 \mathrm{~h}$ along with similar enantiomeric ratios (er=84:16 and 85:15) (Table 2, entry 8). Finally, by using dichloroethane (DCE) as solvent, the enantiomeric ratio of both diastereomers could be somewhat improved (er= 92:8 and 88:12) without erosion of the yield (Table 2, entry 9).

Table 2. Screening reaction conditions for asymmetric aminocatalyzed cascade synthesis of 1,4-DHPs $1 a-i^{a, b}$ 


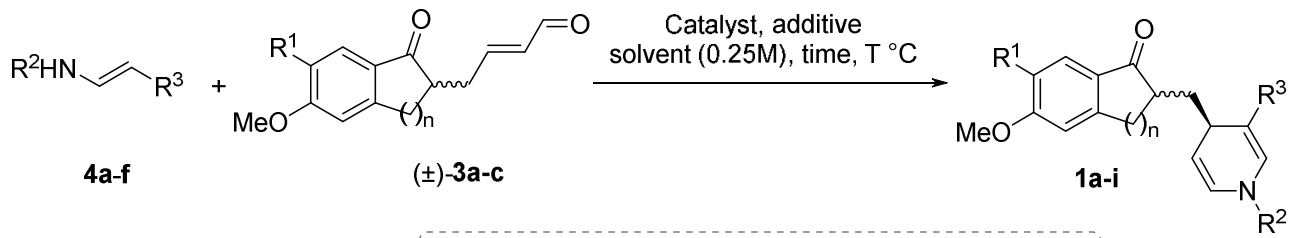

\begin{tabular}{|c|c|c|c|c|c|c|c|c|c|c|}
\hline Entry & 3 & 4 & Cat. & Additive & Solvent & $\begin{array}{l}\text { Time } \\
\text { (h) }\end{array}$ & Cpd & $\begin{array}{l}\text { Yield } \\
(\%)\end{array}$ & $\begin{array}{c}d r^{J} \\
\text { major } \\
\text { /minor }\end{array}$ & $\begin{array}{c}e r^{k} \\
\text { major /minor }\end{array}$ \\
\hline $1^{c}$ & $3 a$ & $4 a$ & I & TFA, $\mathrm{Na}_{2} \mathrm{SO}_{4}$ & DCE & 16 & $1 a$ & - & - & - \\
\hline $2^{d}$ & $3 a$ & $4 a$ & II & BA & toluene & 18 & $1 a$ & traces & - & - \\
\hline $3^{d}$ & $3 a$ & $4 a$ & (S)-III & BA & toluene & 18 & $1 a$ & $10-30^{h}$ & - & $88: 12$ / 88:12 \\
\hline $4^{e}$ & $3 a$ & $4 a$ & (S)-III & BA & toluene & 36 & $1 a$ & traces & - & - \\
\hline $5^{f}$ & $3 a$ & $4 a$ & (S)-III & BA & toluene & 36 & $1 a$ & 30 & $52 / 48$ & $88: 12$ / 87:13 \\
\hline $6^{d}$ & $3 a$ & $4 a$ & (S)-III & BA, MS $3 \AA^{i}$ & toluene & 18 & $1 a$ & 35 & $52 / 48$ & $87: 13 / 86: 14$ \\
\hline $7^{d}$ & $3 a$ & $4 a$ & (S)-III & $\mathrm{BA}, \mathrm{MS} 4 \AA^{i}$ & toluene & 18 & $1 a$ & 49 & $51 / 49$ & $88: 12 / 88: 12$ \\
\hline $8^{g}$ & $3 a$ & $4 a$ & (S)-III & Saccharin & toluene & 0.5 & $1 a$ & 60 & $55 / 45$ & $84: 16 / 85: 15$ \\
\hline $9^{g}$ & $3 a$ & $4 a$ & (S)-III & Saccharin & DCE & 2 & $1 a$ & 61 & $60 / 40$ & 92:8 / 88:12 \\
\hline $10^{g}$ & $3 b$ & $4 a$ & (S)-III & Saccharin & DCE & 2 & $1 b$ & 45 & $52 / 48$ & $93: 7 / 93: 7$ \\
\hline $11^{g}$ & $3 b$ & $4 b$ & (S)-III & Saccharin & DCE & 2 & $1 c$ & 55 & $58 / 42$ & $93: 7 / 95: 5$ \\
\hline $12^{g}$ & $3 b$ & $4 c$ & (S)-III & Saccharin & DCE & 4 & $1 d$ & 47 & $57 / 43$ & 89:11 / 88:12 \\
\hline $13^{g}$ & $3 b$ & $4 d$ & (S)-III & Saccharin & DCE & 8 & $1 e$ & 65 & $55 / 45$ & $92: 8$ / $91: 9$ \\
\hline $14^{g}$ & $3 c$ & $4 a$ & (S)-III & Saccharin & DCE & 4 & $1 f$ & 56 & $53 / 47$ & $90: 10$ / 91:9 \\
\hline $15^{g}$ & $3 c$ & $4 e$ & (S)-III & Saccharin & DCE & 2 & $1 \mathrm{~g}$ & 62 & $51 / 49$ & $92: 8 / 92: 8$ \\
\hline $16^{g}$ & $3 c$ & $4 f$ & (S)-III & Saccharin & DCE & 2 & $1 \mathrm{~h}$ & 54 & $52 / 48$ & $88: 12$ / 94:6 \\
\hline $17^{g}$ & $3 b$ & $4 f$ & (S)-III & Saccharin & DCE & 2 & $1 \mathrm{i}$ & 52 & $55 / 45$ & $87: 13$ / 90:10 \\
\hline $18^{g}$ & $3 c$ & $4 f$ & $(R)$-III & Saccharin & DCE & 4 & $1 h^{\prime}$ & 51 & $53 / 47$ & $84: 16 / 86: 14$ \\
\hline $19^{g}$ & $3 b$ & $4 f$ & $(R)-$ III & Saccharin & DCE & 4 & $1 i^{l}$ & 52 & $58 / 42$ & $86: 14$ / 89:11 \\
\hline
\end{tabular}

${ }^{a}$ Configuration assigned according to the predicted model reported by Kanger ${ }^{7 e} .{ }^{b}$ Reaction conditions: all reactions were performed under argon atmosphere. ${ }^{c} \boldsymbol{3}$ (1.4 equiv), 4 (1.0 equiv), I (40 mol\%), TFA (40 mol\%), $\mathrm{Na}_{2} \mathrm{SO}_{4}\left(3.0\right.$ equiv.), rt. ${ }^{d} \boldsymbol{3}$ (1.0 equiv), 4 (1.0 equiv), catalyst (20 mol\%), benzoic acid $(20 \mathrm{~mol} \%)$, rt. ${ }^{e} 10 \mathrm{~mol} \%$ of catalyst was used. ${ }^{f} 30 \mathrm{~mol} \%$ of catalyst was used. ${ }^{g} 3$ (1.0 equiv), 4 (1.0 equiv), III $(20 \mathrm{~mol} \%)$, Saccharin $(40 \mathrm{~mol} \%), 40{ }^{\circ} \mathrm{C} .{ }^{h}$ reaction performed in triplicate. ${ }^{i}$ Molecular sieves $(0.4 \mathrm{~g} / \mathrm{mmol}) .{ }^{j}$ Diasteromeric ratio determined by HPLC. ${ }^{k}$ Enantiomeric ratio determined by chiral HPLC. ${ }^{\prime}$ Opposite configuration was obtained.

Having determined the optimal conditions, we next examined the scope of the reaction by reacting enamines 4a-f with enals ( \pm )-3b-c (Entries 10-19). Firstly, enamines 4a-d with either a benzyl, phenyl or $n$-propyl group reacted efficiently with racemic aldehyde $( \pm)-3 b$ to lead to the corresponding 1,4-DHPs $1 \mathbf{b}-\mathbf{e}$ in 45 to $65 \%$ yields and good enantiomeric ratios ranging from $88: 12$ to $95: 5$ (Table 2, entries $10-13$ ). Comparable yield (56\%) and enantiomeric ratios (er= 90:10 and 91:9) were obtained by reacting enal ( \pm )-3c possessing an indanone moiety and enamine ( \pm )-4a (Table 2, entry 14). Pleasingly, the method was efficiently applied to the preparation of 1,4-DHPs having an ester or a nitrile functional group at the C-3 position (Table 2, entries 15-19). Thus, when the $\beta$-enamino ester $4 \mathbf{e}$ was reacted with enal $( \pm)-3 \mathbf{c}$, 
the 1,4-DHP $1 \mathrm{~g}$ was isolated in $62 \%$ yield and an enantiomeric ratio up to $92: 8$ (Table 2, Entry 15).

Similarly, the reaction between $\beta$-enamino nitrile $\mathbf{4 f}$ and enal $( \pm)-3 \mathbf{b}$ or $( \pm)-\mathbf{3 c}$ afforded the

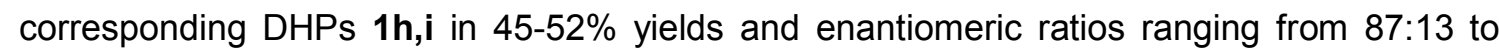
94:6 (Table 2, entries 16-17). Unsurprisingly, when $R$-III catalyst was used instead of $S$-III catalyst, DHPs $1 \mathrm{~h}, \mathrm{i}$ were obtained with comparable yields (51-52\%) and an inversion of the enantiomeric ratios ranging from $84: 16$ to $89: 11$ (Entries 18-19).

To achieve our initial goal, namely the asymmetric synthesis of each of the four stereoisomers of 1,4-DHP 1a, both enals $(S)$-3a and $(R)$-3a were prepared in a three-step sequence including an enantioselective Tsuji allylation as key step (Scheme 3). Thus, the required allyl carbonate 6 was prepared in a good yield (71\%) by adding allyl chloroformate to a mixture of $\alpha$-tetralone $2 \mathrm{a}$ previously treated with KHMDS and TMEDA in THF at $-78{ }^{\circ} \mathrm{C} .{ }^{11}$

\section{Scheme 3. Synthesis of the four stereoisomers of the target prodrug 1a}
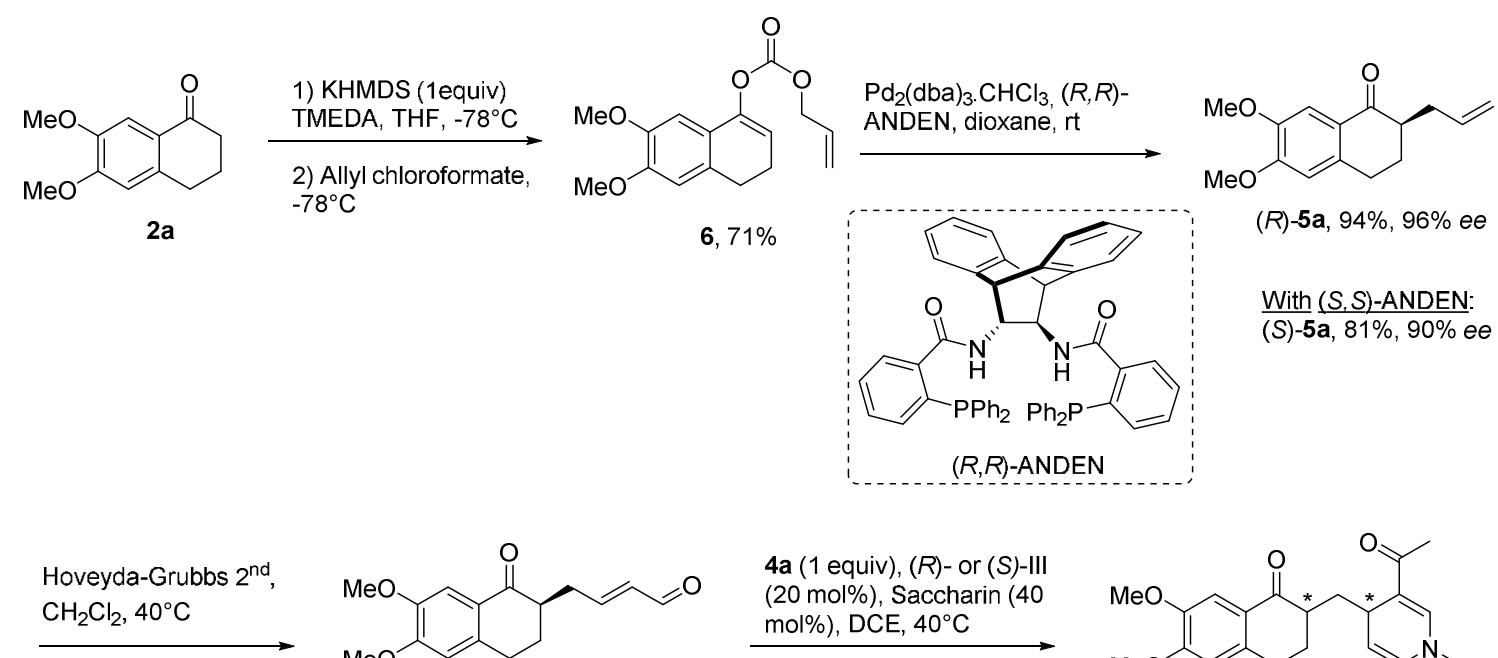

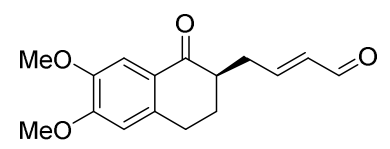

(R)-3a, 96\%, 95\% ee From (S)-5a: (S)-3a, $83 \%, 90 \%$ ee

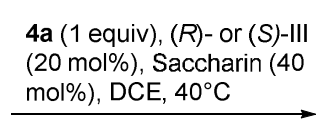

see results in Table 3

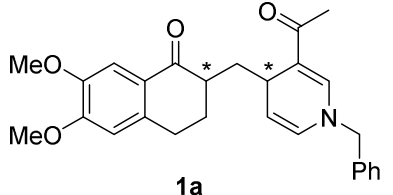

$1 \mathrm{a}$

The so-obtained carbonate 6 was subjected to a palladium-catalyzed decarboxylative asymmetric allylic alkylation (Pd-DAAA) reaction to yield the $\alpha$-allyl ketones $\mathbf{5 a}$. $^{12}$ So, a 
solution of $\mathrm{Pd}_{2}(\mathrm{dba})_{3}$ and $(R, R)$ - or $(S, S)$-ANDEN Trost ligand in 1,4-dioxane was stirred for 30 minutes at room temperature prior to cannulation of the resulting mixture into a solution of allyl carbonate $\mathbf{6}$. Following this procedure, $\alpha$-allyl ketones (R)-5a and (S)-5a were obtained in very good yields (81-94\%) and high enantiomeric ratios (er= 98:2 and 95:5 respectively). Both $\alpha$-allyl ketones (R)-5a and (S)-5a were subjected to cross-metathesis furnishing enals (R)-3a and (S)-3a in good yields (96 and 83\% respectively) without affecting enantiomeric ratios (er= 98:2 and 95:5 respectively). Lastly, enals $(R)$-3a and $(S)$-3a were engaged in the enantioselective organocatalytic aza-ene-type domino reaction with enaminone $4 \mathbf{a}$ in presence of $(S)$ - or $(R)$-Jørgensen-Hayashi catalyst III and saccharin as cocatalyst (Table 3).

Table 3. Enantioselective organocatalytic aza-ene type domino reaction with enals $(S)$ - or $(R)$-3a

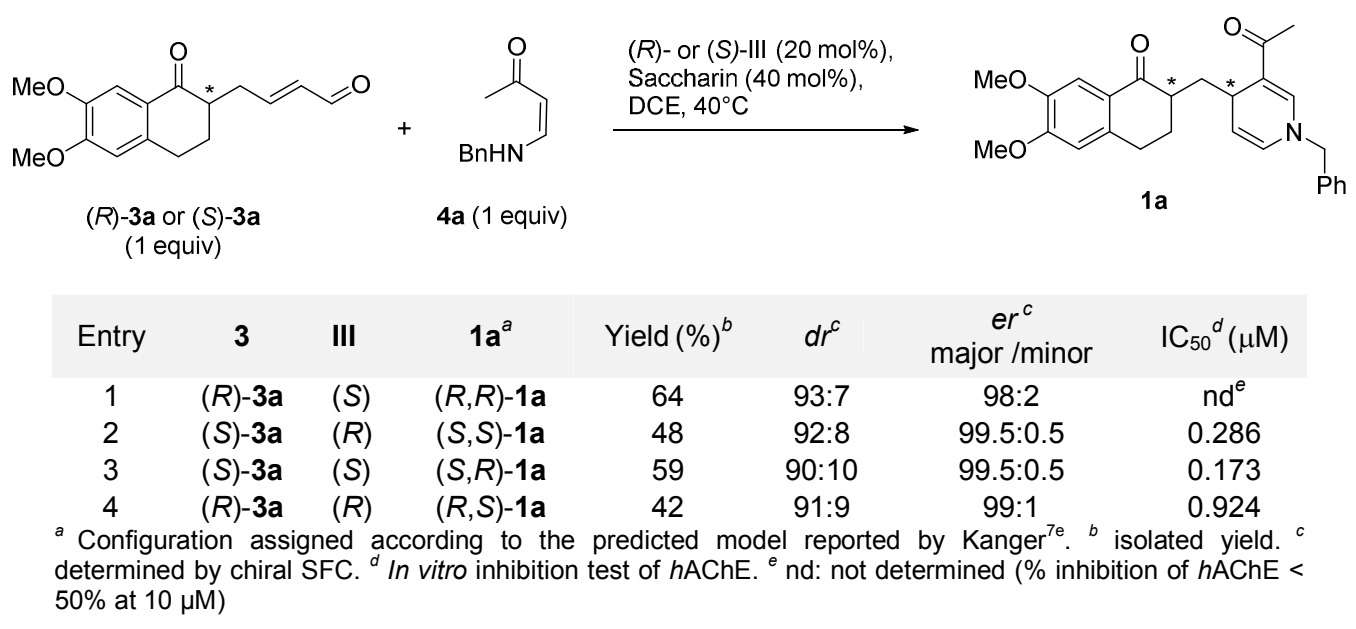

Therefore, using (S)- or $(R)$-III catalyst, enal $(R)$-3a afforded, respectively diastereomers $(R, R)-1 \mathrm{a}$ and $(R, S)-1 \mathrm{a}$ in good yields $(64 \%$ and $42 \%$ respectively) with excellent diastereomeric and enantiomeric ratios ( $d r=93: 7$ and $e r=98: 2$; and $d r=91: 9$ and $e r=99: 1$ respectively). Then, in presence of $(S)$ - or $(R)$-III, enal $(S)$-3a led respectively to the formation of diastereomers $(S, R)-1 \mathrm{a}$ and $(S, S)-1 \mathrm{a}$ in good yields (59\% and $48 \%$ respectively) along with excellent diastereomeric and enantiomeric ratios ( $d r=91: 9$ and $e r=99.5: 0.5$; and $d r=$ 91:9 and er= 99.5:0.5 respectively). Thus, the absolute configuration of the four 
stereoisomers A-D previously isolated by chiral super critical fluid chromatography was assigned affording valuable informations on the structure-activity relationship. Firstly, the configuration of the chiral center carried by the dihydropyridine moiety appears to have a minor impact on the inhibitory activity against $h \mathrm{AChE}$ (Table 3, entries 1 vs 4 / entries 2 vs 3). On the contrary, the tetralone's stereogenic center seems to have a greater influence on the capacity of 1a to inhibit the enzyme activity. Whereas the diastereomers $(S, S)-1$ a and $(S, R)$ 1a display low $\mathrm{IC}_{50}$ values (Table 3 , entries 2 and 3 ), much weaker inhibitory activity is observed for the stereomers with the $(R)$ configuration at the carbon atom adjacent to the carbonyl group of the tetralone (Table 3, entries 1 and 4).

\section{CONCLUSION}

In conclusion, an asymmetric approach toward a family of chiral donepezil-like 1,4dihydropyridines $\mathbf{1}$, highly sought-after as anti-Alzheimer prodrugs, was developed by implementing two highly stereoselective key steps; i.e. a catalytic enantioselective Tsuji allylation from enol carbonate 6 and an enantioselective organocatalytic aza-ene-type domino reaction between enals 3a-c and $\beta$-enaminones or $\beta$-enamino esters $4 a-f$. It should be noticed that the reaction conditions initially reported by Kanger et al. ${ }^{7 e}$ had to be adapted by means of saccharin as co-catalyst to boost the yield (45-65\%) and dichloroethane as solvent to increase the enantiomeric ratio of 1,4-DHPs 1 (er up to 95:5). This stereoselective route toward chiral donepezil-like 1,4-dihydropyridine prodrugs 1 provides a useful extension of known asymmetric transformations to the development of promising chiral prodrug prototypes. ${ }^{4 e-f}$ In addition, the opportunity to have a robust access to all stereoisomers of prodrugs 1 will enable us to accelerate the lead optimization phase while securing the chemical development of this new class of anti-Alzheimer drugs.

\section{EXPERIMENTAL SECTION}


General Information: All commercial reagents were used without further purification. The solvents were dried with appropriate desiccants and distilled prior to use or were obtained anhydrous from commercial suppliers. Silica gel (60, 230-400 mesh or 70-230 mesh) was used for column chromatography. Reactions were monitored by thin layer chromatography on silica gel precoated aluminium plates. UV light at $254 \mathrm{~nm}$ or $\mathrm{KMnO}_{4}$ stains were used to visualize TLC plates. ${ }^{1} \mathrm{H},{ }^{13} \mathrm{C}\left\{{ }^{1} \mathrm{H}\right\}$ NMR spectra were recorded using a spectrometer operating at 300 and $75 \mathrm{MHz}$ respectively. Abbreviations used for peak multiplicities are s: singlet, d: doublet, t: triplet, q: quadruplet, dd: doublet of doublet, br: broad and m: multiplet. Coupling constants $\mathrm{J}$ are in $\mathrm{Hz}$ and chemical shifts are given in ppm and calibrated with DMSO- $d_{6}$ or $\mathrm{CDCl}_{3}$ (residual solvent signals). ${ }^{1} \mathrm{H}$ NMR spectra obtained in $\mathrm{CDCl}_{3}$ were referenced to 7.26 ppm and in DMSO- $d_{6}$ were referenced to $2.50 \mathrm{ppm} .{ }^{13} \mathrm{C}\left\{{ }^{1} \mathrm{H}\right\}$ NMR spectra obtained in $\mathrm{CDCl}_{3}$ were referenced to $77.16 \mathrm{ppm}$. High resolution mass spectra were measured by ESI. Microwave experiments were conducted in a monomode cavity with a microwave power delivery system ranging from 0 to $850 \mathrm{~W}$ allowing pressurized reactions ( 0 to 30 bars) to be carried out in sealed glass vials (4 to $30 \mathrm{~mL}$ ) equipped a snap cap and a silicon septum. The temperature $\left(0\right.$ to $\left.300^{\circ} \mathrm{C}\right)$ was monitored via a contact-less infrared sensor and was calibrated with a ruby Thermometer. Diasteromeric ratios were determined by reversedphase HPLC using Accucore C18 column $\left(150 \times 2.1 \mathrm{~mm}, 2.6 \mu \mathrm{m}\right.$, flow= $\left.0.3 \mathrm{~mL} \cdot \mathrm{min}^{-1}\right)$ with UV detection using a gradient ( 20 to $55 \%$ ) of acetonitrile in ammonium acetate buffer ( $20 \mathrm{mM})$.

2-allyl-6,7-dimethoxy-tetralone-1-one ((\$)-5a). In a microwave vial, to a solution of $2 a$ (412.5 mg, $2.0 \mathrm{mmol})$ and allyl alcohol $(0.68 \mathrm{~mL}, 10.0 \mathrm{mmol})$ in dry toluene $(3 \mathrm{~mL})$ were added freshly distilled 2,2-dimethoxypropane $(0.37 \mathrm{~mL}, 3.0 \mathrm{mmol}), p$-toluenesulfonic acid (68.8 mg, $0.4 \mathrm{mmol}$ ) and $3 \AA$ molecular sieves (ca. $600 \mathrm{mg}$ ). The vial was sealed and heated in a microwave reactor at $200{ }^{\circ} \mathrm{C}$ for $1.5 \mathrm{~h}$. The cooled reaction mixture was diluted with $\mathrm{CH}_{2} \mathrm{Cl}_{2}(20 \mathrm{~mL})$ and washed successively with saturated aqueous solution of $\mathrm{NaHCO}_{3}$ and brine. The combined organic phase was dried over $\mathrm{MgSO}_{4}$ and concentrated to dryness. The residue was purified by column chromatography (Petroleum ether/EtOAc $=3: 1$ ) to afford the 
title compound ( \pm )-5a as a colorless oil $(247.1 \mathrm{mg}, 50 \%) .{ }^{1} \mathrm{H} \mathrm{NMR}\left(300 \mathrm{MHz}, \mathrm{CDCl}_{3}\right) \delta 7.51$ (s, 1H), $6.64(\mathrm{~s}, 1 \mathrm{H}), 5.91-5.76(\mathrm{~m}, 1 \mathrm{H}), 5.12-5.04(\mathrm{~m}, 2 \mathrm{H}), 3.92(\mathrm{~s}, 3 \mathrm{H}), 3.90(\mathrm{~s}, 3 \mathrm{H}), 2.95-$ $2.85(\mathrm{~m}, 2 \mathrm{H}), 2.78-2.71(\mathrm{~m}, 1 \mathrm{H}), 2.55-2.40(\mathrm{~m}, 1 \mathrm{H}), 2.32-2.14(\mathrm{~m}, 2 \mathrm{H}), 1.92-1.78(\mathrm{~m}, 1 \mathrm{H}) .{ }^{13} \mathrm{C}$ NMR $\left(75 \mathrm{MHz}, \mathrm{CDCl}_{3}\right) \delta 198.4,153.4,147.9,138.9,136.4,125.7,116.8,110.1,108.8,56.0$, 55.9, 46.5, 34.2, 28.3, 28.2. HRMS $\left(E S I^{+}\right.$) calcd for $[M+H]^{+} \mathrm{C}_{15} \mathrm{H}_{19} \mathrm{O}_{3} \mathrm{~m} / \mathrm{z} 247.1334$, found 247.1323.

2-allyl-6-methoxy-tetralone-1-one (( \pm )-5b). To a solution of LiHMDS (4.15 g, $24.8 \mathrm{mmol})$ in THF $(20 \mathrm{~mL})$ cooled at $-78^{\circ} \mathrm{C}$ was added slowly a solution of $\mathbf{2 b}(3.5 \mathrm{~g}, 19.86 \mathrm{mmol})$ in dry THF $(60 \mathrm{~mL})$. After the addition was complete, the solution was stirred at $-78^{\circ} \mathrm{C}$ for 30 minutes, then HMPA ( $7 \mathrm{~mL}, 40.2 \mathrm{mmol}$ ) was added slowly and stirred for other 5 minutes followed by the addition of a solution of allyl bromide $(2.6 \mathrm{~mL}, 30.08 \mathrm{mmol})$ in dry THF (10 $\mathrm{mL}$ ) at the same temperature. The mixture was left to warm slowly to room temperature (2$3 \mathrm{~h})$ and quenched at $0^{\circ} \mathrm{C}$ with aqueous $1 \mathrm{~N} \mathrm{HCl}(20 \mathrm{~mL})$, and then extracted with diethyl ether (3x). The combined organic phase was dried over $\mathrm{MgSO}_{4}$ and concentrated to dryness. The residue was purified by column chromatography (Petroleum ether/EtOAc $=95: 5$ ) to afford the title compound $( \pm)-5 \mathbf{b}$ as a colorless oil $(2.9 \mathrm{~g}, 68 \%) .{ }^{1} \mathrm{H}$ NMR $\left(300 \mathrm{MHz}, \mathrm{CDCl}_{3}\right) \delta 8.01(\mathrm{~d}, J$ $=8.8 \mathrm{~Hz}, 1 \mathrm{H}), 6.82(\mathrm{dd}, J=8.7,2.5 \mathrm{~Hz}, 1 \mathrm{H}), 6.68(\mathrm{~d}, J=2.4 \mathrm{~Hz}, 1 \mathrm{H}), 5.97-5.73(\mathrm{~m}, 1 \mathrm{H})$, 5.13-5.04 (m, 2H), $3.85(\mathrm{~s}, 3 \mathrm{H}), 2.95-2.93(\mathrm{~m}, 2 \mathrm{H}), 2.81-2.67(\mathrm{~m}, 1 \mathrm{H}), 2.58-2.42(\mathrm{~m}, 1 \mathrm{H})$, 2.34-2.13 (m, 2H), 1.94-1.74 (m, 1H). ${ }^{13} \mathrm{C}$ NMR (75 MHz, $\left.\mathrm{CDCl}_{3}\right) \delta 198.4,163.5,146.7$, 136.6, 130.0, 126.3, 116.9, 113.2, 112.6, 55.6, 46.9, 34.3, 29.1, 28.1. HRMS $\left(\mathrm{ESI}^{+}\right)$calcd for $[\mathrm{M}+\mathrm{Na}]^{+} \mathrm{C}_{14} \mathrm{H}_{16} \mathrm{O}_{2} \mathrm{Na}^{+} \mathrm{m} / \mathrm{z} 239.1048$, found 239.1043.

2-allyl-5,6-dimethoxy-indan-1-one ((士)-5c). From LiHMDS $(0.8 \mathrm{~g}, 4.78 \mathrm{mmol})$ in THF (40 $\mathrm{mL}), 2 \mathrm{c}(1.0 \mathrm{~g}, 5.2 \mathrm{mmol})$ in THF $(40 \mathrm{~mL}), \mathrm{HMPA}(1.7 \mathrm{~mL}, 9.56 \mathrm{mmol})$, allyl bromide $(0.86$ $\mathrm{mL}, 7.17 \mathrm{mmol})$ diluted in THF $(5 \mathrm{~mL})$ and following the procedure described for the synthesis of compound ( \pm )-5b, the title compound $( \pm)-5 c$ was obtained as a colorless oil $(0.5$ $\mathrm{g}, 46 \%)$ after purification by column chromatography on silica gel (Petroleum ether/EtOAc $=$ 2:1). ${ }^{1} \mathrm{H}$ NMR (300 MHz, $\left.\mathrm{CDCl}_{3}\right) \delta 7.13(\mathrm{~s}, 1 \mathrm{H}), 6.83$ (s, 1H), 5.83-5.68 (m, 1H), 5.13-5.00 (m, 
2H), 3.93 (s, 3H), 3.87 (s, 3H), $3.15(\mathrm{dd}, J=17.7,8.0 \mathrm{~Hz}, 1 \mathrm{H}), 2.79-2.57(\mathrm{~m}, 3 \mathrm{H}), 2.29-2.12$ $(\mathrm{m}, 1 \mathrm{H}) .{ }^{13} \mathrm{C}$ NMR $\left(75 \mathrm{MHz}, \mathrm{CDCl}_{3}\right) \delta 206.9,155.6,149.4,149.1,135.6,129.4,116.9,107.4$, 104.3, 56.2, 56.1, 46.8, 35.8, 31.8. HRMS (ESI ${ }^{+}$) calcd for $[\mathrm{M}+\mathrm{H}]^{+} \mathrm{C}_{14} \mathrm{H}_{17} \mathrm{O}_{3} \mathrm{~m} / \mathrm{z} 233.1178$ found 233.1175 .

General procedure for the synthesis of enal derivatives 3a-c: Under Argon atmosphere, crotonaldehyde $(20 \mathrm{mmol})$ was added to a solution of the corresponding allyl derivative $5 \mathbf{a}-\mathbf{c}$ (5.0 mmol) in degassed $\mathrm{CH}_{2} \mathrm{Cl}_{2}(10.0 \mathrm{~mL})$. Hoveyda-Grubbs' $2^{\text {nd }}(2.5 \% \mathrm{~mol})$ was then added, and the reaction mixture was heated to $40{ }^{\circ} \mathrm{C}$ overnight. After cooling at room temperature, the reaction mixture was filtered over Celite ${ }^{\circledR}$ and the filtrate was concentrated to dryness and purified by column chromatography on silica gel to give the expected aldehydes 3a-c.

(E)-4-(6,7-dimethoxy-1-oxo-tetralon-2-yl)but-2-enal (( \pm )-3a). From crotonaldehyde (182.0 mg, $2.6 \mathrm{mmol}),( \pm)-5 \mathrm{a}(160.0 \mathrm{mg}, 0.65 \mathrm{mmol})$, Hoveyda-Grubbs' $2^{\text {nd }}(10 \mathrm{mg}, 5 \% \mathrm{~mol})$ and $\mathrm{CH}_{2} \mathrm{Cl}_{2}(5.0 \mathrm{~mL})$. Purification by column chromatography on silica gel (Petroleum ether/EtOAc $=1: 1)$ gave $( \pm)-3 \mathbf{a}$ as an off-white powder $(146.0 \mathrm{mg}, 82 \%) .{ }^{1} \mathrm{H} \mathrm{NMR}(300 \mathrm{MHz}$, $\left.\mathrm{CDCl}_{3}\right) \delta 9.51(\mathrm{~d}, J=7.9 \mathrm{~Hz}, 1 \mathrm{H}), 7.49(\mathrm{~s}, 1 \mathrm{H}), 6.98-6.88(\mathrm{~m}, 1 \mathrm{H}), 6.65(\mathrm{~s}, 1 \mathrm{H}), 6.17(\mathrm{dd}, J=$ 15.7, $7.9 \mathrm{~Hz}, 1 \mathrm{H}), 3.92(\mathrm{~s}, 3 \mathrm{H}), 3.90(\mathrm{~s}, 3 \mathrm{H}), 3.05-2.85(\mathrm{~m}, 3 \mathrm{H}), 2.71-2.52(\mathrm{~m}, 2 \mathrm{H}), 2.21-2.12$ $(\mathrm{m}, 1 \mathrm{H}), 1.95-1.78(\mathrm{~m}, 1 \mathrm{H}) .{ }^{13} \mathrm{C}$ NMR $\left(75 \mathrm{MHz}, \mathrm{CDCl}_{3}\right) \delta 197.1,193.8,156.5,153.6,148.0$, 138.8, 134.5, 125.2, 110.1, 108.6, 56.1, 56.0, 46.0, 33.4, 29.0, 28.5. HRMS $\left(\mathrm{ESI}^{+}\right)$calcd for $[\mathrm{M}+\mathrm{H}]^{+} \mathrm{C}_{16} \mathrm{H}_{19} \mathrm{O}_{4} \mathrm{~m} / \mathrm{z} 275.1283$, found 275.1279.

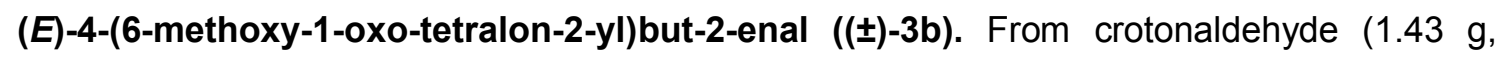
$20.3 \mathrm{mmol}),( \pm)-5 b(1.1 \mathrm{~g}, 5.09 \mathrm{mmol})$, Hoveyda-Grubbs' $2^{\text {nd }}(80.0 \mathrm{mg}, 2.5 \% \mathrm{~mol})$ and $\mathrm{CH}_{2} \mathrm{Cl}_{2}$ $(1.0 \mathrm{~mL})$. Purification by column chromatography on silica gel (Petroleum ether/EtOAc $=4: 1$ ) gave $( \pm)-3 \mathbf{b}$ as an off-white powder $(1.1 \mathrm{~g}, 88 \%) .{ }^{1} \mathrm{H}$ NMR $\left(300 \mathrm{MHz}, \mathrm{CDCl}_{3}\right) \delta 9.52(\mathrm{~d}, \mathrm{~J}=$ $7.9 \mathrm{~Hz}, 1 \mathrm{H}), 8.02(\mathrm{~d}, J=8.8 \mathrm{~Hz}, 1 \mathrm{H}), 7.01-6.82(\mathrm{~m}, 2 \mathrm{H}), 6.69(\mathrm{~d}, J=2.4 \mathrm{~Hz}, 1 \mathrm{H}), 6.19(\mathrm{dd}, J$ $=15.6,7.9 \mathrm{~Hz}, 1 \mathrm{H}), 3.86(\mathrm{~s}, 3 \mathrm{H}), 3.04-2.91(\mathrm{~m}, 3 \mathrm{H}), 2.71-2.52(\mathrm{~m}, 2 \mathrm{H}), 2.29-2.09(\mathrm{~m}, 1 \mathrm{H})$, 1.99-1.76 (m, 1H). ${ }^{13} \mathrm{C}$ NMR $\left(75 \mathrm{MHz}, \mathrm{CDCl}_{3}\right) \delta 197.1,194.0,163.8,156.7,146.5,134.7$, 
$\left.130.1,125.9,113.5,112.6,55.6,46.6,33.5,29.4,28.9 . \mathrm{HRMS}_{(\mathrm{ESI}}{ }^{+}\right)$calcd for $[\mathrm{M}+\mathrm{Na}]^{+}$ $\mathrm{C}_{15} \mathrm{H}_{16} \mathrm{O}_{3} \mathrm{Na} \mathrm{m} / \mathrm{z} 267.0997$ found 267.1003 .

(E)-4-(5,6-dimethoxy-1-oxo-indan-2-yl)but-2-enal ((士)-3c). From crotonaldehyde $(0.63 \mathrm{mg}$, $0.75 \mathrm{~mL}, 8.99 \mathrm{mmol}),( \pm)-5 \mathrm{c}(0.5 \mathrm{~g}, 2.15 \mathrm{mmol})$, Hoveyda-Grubbs' $2^{\text {nd }}(17.0 \mathrm{mg}, 2.5 \% \mathrm{~mol})$ and dichloromethane $(15 \mathrm{~mL})$. Purification by column chromatography on silica gel (Petroleum ether/EtOAc $=1: 1)$ gave $( \pm)-3 \mathrm{c}$ as an yellow solid $(0.51 \mathrm{~g}, 91 \%) .{ }^{1} \mathrm{H}$ NMR $(300$ $\left.\mathrm{MHz}, \mathrm{CDCl}_{3}\right) \delta 9.51(\mathrm{~d}, J=7.8 \mathrm{~Hz}, 1 \mathrm{H}), 7.18(\mathrm{~s}, 1 \mathrm{H}), 7.02-6.78(\mathrm{~m}, 2 \mathrm{H}), 6.19(\mathrm{dd}, J=15.7$, $7.8 \mathrm{~Hz}, 1 \mathrm{H}), 3.97(\mathrm{~s}, 3 \mathrm{H}), 3.92(\mathrm{~s}, 3 \mathrm{H}), 3.27(\mathrm{dd}, J=16.9,7.4 \mathrm{~Hz}, 1 \mathrm{H}), 3.02-2.83(\mathrm{~m}, 2 \mathrm{H})$, $2.71(\mathrm{dd}, J=17.0,3.3 \mathrm{~Hz}, 1 \mathrm{H}), 2.62-2.47(\mathrm{~m}, 1 \mathrm{H}) .{ }^{13} \mathrm{C}$ NMR $\left(75 \mathrm{MHz}, \mathrm{CDCl}_{3}\right) \delta$ 205.5, 193.9, $156.1,155.3,149.8,148.7,134.6,129.0,107.5,104.5,56.5,56.3,46.0,34.7,32.1$. HRMS $\left(\mathrm{ESI}^{+}\right)$calcd for $[\mathrm{M}+\mathrm{H}]^{+} \mathrm{C}_{15} \mathrm{H}_{17} \mathrm{O}_{4} \mathrm{~m} / \mathrm{z} 261.1126$, found 261.1131 .

General procedure for the synthesis of enamines 4a-f: A mixture of the corresponding commercial enol ether $(5.0 \mathrm{mmol})$ and commercial amine $(5.0 \mathrm{mmol})$ was heated under vacuum. The methanol by-product was eliminated as it forms, affording only the expected enamines 4a-f which were used without further purification.

(Z)-4-(benzylamino)but-3-en-2-one (4a). From 4-methoxy-3-buten-2-one (500.0 mg, 5.0 $\mathrm{mmol}$ ) and benzylamine $(535.0 \mathrm{mg}, 5.0 \mathrm{mmol})$. The mixture was heated to $60^{\circ} \mathrm{C}$ for $50 \mathrm{~min}$ to give enaminone $4 \mathrm{a}$ as an yellow oil (875.0 mg, 100\%). ${ }^{1} \mathrm{H} \mathrm{NMR}\left(300 \mathrm{MHz}, \mathrm{CDCl}_{3}\right) \delta 10.07$ (br s, 1H), 7.37-7.24 (m, 5H), $6.71(\mathrm{dd}, J=12.7,7.4 \mathrm{~Hz}, 1 \mathrm{H}), 5.06(\mathrm{~d}, J=7.4 \mathrm{~Hz}, 1 \mathrm{H}), 4.38$ (d, $J=6.1 \mathrm{~Hz}, 2 \mathrm{H}), 2.08$ (s, 3H). ${ }^{13} \mathrm{C}$ NMR $\left(75 \mathrm{MHz}, \mathrm{CDCl}_{3}\right) \delta 197.8,152.4,138.0,128.9$, 128.8, 127.8, 127.5, 127.1, 94.5, 52.5, 29.1. HRMS (ESI ${ }^{+}$, calcd for $\mathrm{C}_{11} \mathrm{H}_{14} \mathrm{NO} 176.10699$ found 176.10685 .

(Z)-4-((2-methylbenzyl)amino)but-3-en-2-one (4b). From 4-methoxy-3-buten-2-one (801.0 $\mathrm{mg}, 8.0 \mathrm{mmol})$ and 2-methylbenzylamine $(969.0 \mathrm{~g}, 8.0 \mathrm{mmol})$. The mixture was heated to $60^{\circ} \mathrm{C}$ for $30 \mathrm{~min}$ to give enaminone $4 \mathrm{~b}$ as an yellow oil $(1.50 \mathrm{mg}, 99 \%) .{ }^{1} \mathrm{H}$ NMR $(300 \mathrm{MHz}$, $\left.\mathrm{CDCl}_{3}\right) \delta 10.05(\mathrm{~s}, 1 \mathrm{H}), 7.25-7.02(\mathrm{~m}, 4 \mathrm{H}), 6.67(\mathrm{dd}, J=12.7,7.4 \mathrm{~Hz}, 1 \mathrm{H}), 5.04(\mathrm{~d}, J=7.4$ $\mathrm{Hz}, 1 \mathrm{H}), 4.35(\mathrm{~d}, J=5.9 \mathrm{~Hz}, 2 \mathrm{H}), 2.31(\mathrm{~s}, 3 \mathrm{H}), 2.06(\mathrm{~s}, 3 \mathrm{H}) \cdot{ }^{13} \mathrm{C} \mathrm{NMR}\left(75 \mathrm{MHz}, \mathrm{CDCl}_{3}\right) \delta$ 
$197.8,152.3,136.0,135.8,130.7,128.0,127.9,126.5,94.5,50.7,29.2,19.2$. HRMS $\left._{(E S I}{ }^{+}\right)$ calcd for $[\mathrm{M}+\mathrm{H}]^{+} \mathrm{C}_{12} \mathrm{H}_{16} \mathrm{NO} \mathrm{m} / \mathrm{z}$ 190.1231, found 190.1232 .

(Z)-4-(phenylamino)but-3-en-2-one (4c). From 4-methoxy-3-buten-2-one (1.0 g, $10.0 \mathrm{mmol})$ and aniline $(931.0 \mathrm{mg}, 10.0 \mathrm{mmol})$. The mixture was heated to $60^{\circ} \mathrm{C}$ for $40 \mathrm{~min}$ to give enaminone $4 \mathrm{c}$ as a red oil (1.52 g, 94\%). ${ }^{1} \mathrm{H}$ NMR (300 MHz, $\left.\mathrm{CDCl}_{3}\right) \delta 11.60$ (br s, 1H), 7.33$7.18(\mathrm{~m}, 3 \mathrm{H}), 7.06-7.00(\mathrm{~m}, 3 \mathrm{H}), 5.29(\mathrm{~d}, J=7.7 \mathrm{~Hz}, 1 \mathrm{H}), 2.15(\mathrm{~s}, 3 \mathrm{H}) .{ }^{13} \mathrm{C}$ NMR $(75 \mathrm{MHz}$, $\left.\mathrm{CDCl}_{3}\right) \delta 199.0,143.1,140.4,129.8,123.5,116.2,97.5,29.7 . \mathrm{HRMS}(\mathrm{ESI}+)$ calcd for $[\mathrm{M}+\mathrm{H}]^{+}$ $\mathrm{C}_{10} \mathrm{H}_{12} \mathrm{NO} \mathrm{m} / \mathrm{z}$ 162.0919, found 162.0911.

(Z)-4-(propylamino)but-3-en-2-one (4d). From 4-methoxy-3-buten-2-one (1.0 g, $10.0 \mathrm{mmol})$ and $n$-propylamine $(591.0 \mathrm{mg}, 10.0 \mathrm{mmol})$. The mixture was heated to $60{ }^{\circ} \mathrm{C}$ for $2 \mathrm{~h}$ to give enaminone $4 \mathbf{d}$ as a deep orange oil (1.25 g, 98\%). ${ }^{1} \mathrm{H}$ NMR $\left(300 \mathrm{MHz}, \mathrm{CDCl}_{3}\right) \delta 9.81$ ( br s, 1H), 6.62 (dd, $J=12.8,7.3 \mathrm{~Hz}, 1 \mathrm{H}), 4.94(\mathrm{~d}, J=7.3 \mathrm{~Hz}, 1 \mathrm{H}), 3.15-3.09(\mathrm{~m}, 2 \mathrm{H}), 2.02$ (s, 3H), 1.65-1.46 (m, 2H), $0.91(\mathrm{t}, J=7.4 \mathrm{~Hz}, 3 \mathrm{H}) .{ }^{13} \mathrm{C}$ NMR $\left(75 \mathrm{MHz}, \mathrm{CDCl}_{3}\right) \delta 197.3,152.8,93.5$, 50.9, 29.0, 24.4, 11.2. HRMS (ESI+) calcd for $[\mathrm{M}+\mathrm{H}]^{+} \mathrm{C}_{7} \mathrm{H}_{14} \mathrm{NO} \mathrm{m} / \mathrm{z} 128.1075$, found 128.1075.

(E)- and (Z)-methyl 3-((2-methylbenzyl)amino)acrylate (4e). From methyl trans-3methoxyacrylate $(581.0 \mathrm{mg}, 5.0 \mathrm{mmol})$ and 2-methylbenzylamine $(606.0 \mathrm{~g}, 5.0 \mathrm{mmol})$. The mixture was heated to $60^{\circ} \mathrm{C}$ for $16 \mathrm{~h}$ to give compound $4 \mathrm{e}(Z / E=1: 1)$ as an off-white gel (875.0 mg, 85\%). ${ }^{1} \mathrm{H}$ NMR (300 MHz, $\mathrm{CDCl}_{3}$ ) $\delta 8.06$ (s, 0.5H), 7.58 (dd, $J=13.3,7.8 \mathrm{~Hz}$, 0.5H), 7.22-7.14 (m, 4H), $6.66(\mathrm{dd}, J=13.1,8.0 \mathrm{~Hz}, 0.5 \mathrm{H}), 4.82(\mathrm{~d}, J=13.2 \mathrm{~Hz}, 0.5 \mathrm{H}), 4.60$ (br s, $0.5 \mathrm{H}), 4.54(\mathrm{~d}, J=8.0 \mathrm{~Hz}, 0.5 \mathrm{H}), 4.33(\mathrm{~d}, J=5.8 \mathrm{~Hz}, 1 \mathrm{H}), 4.17(\mathrm{~d}, J=5.2 \mathrm{~Hz}, 1 \mathrm{H}), 3.66$ (s, 1.5H), $3.64(\mathrm{~s}, 1.5 \mathrm{H}), 2.31(\mathrm{~s}, 1.5 \mathrm{H}), 2.31(\mathrm{~s}, 1.5 \mathrm{H}) .{ }^{13} \mathrm{C} \mathrm{NMR}\left(75 \mathrm{MHz}, \mathrm{CDCl}_{3}\right) \delta 171.2$, $170.0,152.2,136.6,136.3,136.0,130.8,130.6,128.6,128.3,127.9,127.8,126.5,126.4$, 82.4, 50.7, 50.4, 50.3, 43.6, 19.2, 19.0. HRMS $\left(\mathrm{ESI}^{+}\right)$calcd for $[\mathrm{M}+\mathrm{H}]^{+} \mathrm{C}_{12} \mathrm{H}_{16} \mathrm{NO}_{2} \mathrm{~m} / \mathrm{z}$ 206.1181, found 206.1174.

(Z)-3-(benzylamino)acrylonitrile (4f). From 3-methoxyacrilonitrile (415.0 mg, $2.0 \mathrm{mmol})$ and benzylamine $(535.0 \mathrm{mg}, 5.0 \mathrm{mmol})$. The mixture was heated to $110{ }^{\circ} \mathrm{C}$ for $4 \mathrm{~h}$ to give a yellow 
oil (789.0 mg, 100\%). ${ }^{1} \mathrm{H}$ NMR (300 MHz, $\left.\mathrm{CDCl}_{3}\right) \delta$ 7.40-7.28 (m, 5H), 7.11 (dd, $J=13.8,7.5$ $\mathrm{Hz}, 1 \mathrm{H}), 4.58(\mathrm{br} s, 1 \mathrm{H}), 4.17(\mathrm{~d}, J=5.4 \mathrm{~Hz}, 2 \mathrm{H}), 4.03(\mathrm{~d}, J=13.8 \mathrm{~Hz}, 1 \mathrm{H}) .{ }^{13} \mathrm{C}$ NMR $(75$ $\left.\mathrm{MHz}, \mathrm{CDCl}_{3}\right) \delta 151.0,136.3,128.5,127.5,127.1,122.2,61.3,47.2 . \mathrm{HRMS}\left(\mathrm{ESI}^{+}\right)$calcd for $[\mathrm{M}+\mathrm{H}]^{+} \mathrm{C}_{10} \mathrm{H}_{11} \mathrm{~N}_{2} \mathrm{~m} / \mathrm{z}$ 159.0922, found 159.0924 .

\section{General procedure for the synthesis of 1,4-DHPs 1a-g by scandium triflate catalysis} (Method A). To a suspension of $\mathrm{Sc}(\mathrm{OTf})_{3}(49.1 \mathrm{mg}, 10 \mathrm{~mol} \%), \mathrm{Na}_{2} \mathrm{SO}_{4}(0.42 \mathrm{~g}, 3$ equiv) in dry $\mathrm{CH}_{2} \mathrm{Cl}_{2}(3.5 \mathrm{~mL})$ were added a solution of enamine freshly prepared 4a-f $(1.0 \mathrm{mmol}, 1$ equiv) and enal ( \pm )-3a-c (1.0 mmol, 1 equiv) in dry $\mathrm{CH}_{2} \mathrm{Cl}_{2}(1.5 \mathrm{~mL})$. The mixture was stirred at room temperature $\left(21^{\circ} \mathrm{C}\right)$ until total consumption of enal (TLC). The reaction solution was filtered on Celite ${ }^{\circledR}$ and concentrated under vacuum. The crude residue was purified by column chromatography on silica gel to afford the 1,4-DHPs 1a-g.

General procedure for the synthesis of 1,4-DHPs 1a-i by enantioselective aminocatalysis (Method B). Under argon atmosphere, a mixture of the enal 3a-c (1.0 mmol, 1 equiv), saccharin (73.2 mg, $40 \mathrm{~mol} \%),(R)$ - or $(S)-I I I(65.1 \mathrm{mg}, 20 \mathrm{~mol} \%)$ and the enamine $4 \mathrm{a}-\mathrm{f}$ ( $1.0 \mathrm{mmol}, 1$ equiv) in dry dichloroethane $(0.25 \mathrm{M})$ was stirred at $40^{\circ} \mathrm{C}$ until total consumption of enal (TLC). Upon completion of the reaction and cooling to room temperature, the mixture was diluted with dichloromethane. The resulting solution was then filtered over Celite ${ }^{\circledR}$ and concentrated to dryness. The crude residue was directly purified column chromatography on silica gel to give the desired 1,4-dihydropyridines 1a-i.

\section{2-((3-acetyl-1-benzyl-1,4-dihydropyridin-4-yl)methyl)-6,7-dimethoxy-3,4-}

dihydronaphthalen-1(2H)-one (1a). Method A: From enamine 4a (140. mg, $0.8 \mathrm{mmol})$, ( \pm )3a $(242.0 \mathrm{mg}, 0.88 \mathrm{mmol})$. Purification by column chromatography on silica gel (EtOAc gradient in petroleum ether) gave 1a as a yellow oil (118.1 mg, 62\%). Method B: From enamine 4a (70.1 mg, $0.4 \mathrm{mmol})$, ( \pm )-3a (110.0 mg, $0.4 \mathrm{mmol})$ and (S)-III (20 mol\%). Purification by column chromatography on silica gel (EtOAc gradient in petroleum ether) gave the enantio-enriched DHP 1a (103.5 mg, 60\%). HPLC Chiralpak ${ }^{\circledR}$ IE column; 60/33/7 heptane/DCM/isopropanol; flow rate $=1 \mathrm{~mL} \cdot \mathrm{min}^{-1} ; \mathrm{t}_{1}=26.07 \mathrm{~min}$ (minor), $\mathrm{t}_{2}=28.4 \mathrm{~min}$ 
(minor), $\mathrm{t}_{3}=30.4 \min$ (major), $\mathrm{t}_{4}=43.1 \mathrm{~min}$ (major); $d r=60: 40 ;$ er major $=95: 5 ;$ er minor $=$ 85:5. ${ }^{1} \mathrm{H}$ NMR $\left(300 \mathrm{MHz}, \mathrm{CDCl}_{3}\right) \delta 7.51(\mathrm{~s}, 0.5 \mathrm{H}), 7.49(\mathrm{~s}, 0.5 \mathrm{H}), 7.47-7.11(\mathrm{~m}, 6 \mathrm{H}), 6.65(\mathrm{~s}$, $0.5 \mathrm{H}), 6.62(\mathrm{~s}, 0.5 \mathrm{H}), 5.98-5.93(\mathrm{~m}, 1 \mathrm{H}), 5.09-5.04(\mathrm{~m}, 1 \mathrm{H}), 4.45(\mathrm{~s}, 1 \mathrm{H}), 4.44(\mathrm{~s}, 1 \mathrm{H}), 3.91$ (s, 3H), $3.88(\mathrm{~s}, 3 \mathrm{H}), 3.73-3.68(\mathrm{~m}, 1 \mathrm{H}), 3.21-3.08(\mathrm{~m}, 0.5 \mathrm{H}), 2.91-2.84(\mathrm{~m}, 1.5 \mathrm{H}), 2.73-2.64$ $(\mathrm{m}, 0.5 \mathrm{H}), 2.60-2.48(\mathrm{~m}, 0.5 \mathrm{H}), 2.40-2.05(\mathrm{~m}, 5 \mathrm{H}), 1.95-1.81(\mathrm{~m}, 1 \mathrm{H}), 1.65-1.51(\mathrm{~m}, 0.5 \mathrm{H})$, 1.44-1.32 (m, 0.5H). ${ }^{13} \mathrm{C}$ NMR $\left(75 \mathrm{MHz}, \mathrm{CDCl}_{3}\right) \delta 199.9,199.7,195.4,194.2,153.2,153.1$, $147.7,142.9,142.8,138.9,138.7,136.8,136.7,128.9,128.0,127.9,127.8,126.9,126.8$, $125.6,125.3,113.7,113.3,110.2,110.1,108.7,108.6,108.2,57.8,57.7,56.0,55.9,43.4$, 42.3, 38.1, 37.7, 29.4, 28.3, 28.1, 27.2, 26.8, 24.6, 24.4. HRMS $\left(\mathrm{ESI}^{+}\right)$calcd for $[\mathrm{M}+\mathrm{H}]^{+}$ $\mathrm{C}_{27} \mathrm{H}_{30} \mathrm{NO}_{4} \mathrm{~m} / \mathrm{z}$ 432.2175, found 432.2182.

\section{2-((3-acetyl-1-benzyl-1,4-dihydropyridin-4-yl)methyl)-6-methoxy-3,4-}

dihydronaphthalen-1(2H)-one (1b). Method A: From enamine 4a (140.0 mg, $0.8 \mathrm{mmol})$, ( \pm )-3b (200.0 mg, $0.8 \mathrm{mmol})$. Purification by column chromatography on silica gel (EtOAc gradient in Petroleum ether) gave 1b as a yellow oil (110.0 mg, 35\%). Method B: From enamine $4 \mathrm{a}(71.8 \mathrm{mg}, 0.41 \mathrm{mmol}),( \pm)-3 \mathrm{a}(102.6 \mathrm{mg}, 0.42 \mathrm{mmol})$ and $(S)-\mathrm{III}(20 \mathrm{~mol} \%)$. Purification by column chromatography on silica gel (EtOAc gradient in petroleum ether) gave the enantio-enriched DHP 1b $(74.1 \mathrm{mg}, 45 \%)$. HPLC analytic separation: Chiralpak ${ }^{\circledR}$ IC column; 80/20 heptane/ethanol; flow rate $=1 \mathrm{~mL} \cdot \mathrm{min}^{-1} ; \mathrm{t}_{1}=28.08 \mathrm{~min}$ (major), $\mathrm{t}_{2}=32.6 \mathrm{~min}$ (minor), $\mathrm{t}_{3}=34.6 \mathrm{~min}$ (major), $\mathrm{t}_{4}=37.3 \mathrm{~min}$ (minor); $d r=52: 48 ;$ er major $=93: 7 ;$ er minor $=$ 93:7. ${ }^{1} \mathrm{H}$ NMR $\left(300 \mathrm{MHz}, \mathrm{CDCl}_{3}\right)$ ठ 7.96-7.92 (m, 1H), 7.41-7.16 (m, 6H), 6.82-6.78 (m, 1H), 6.71-6.68 (m, 1H), 5.97-5.92 (m, 1H), 5.08-5.02 (m, 1H), $4.47(\mathrm{~s}, 2 \mathrm{H}), 3.81(\mathrm{~s}, 3 \mathrm{H}), 3.73-3.63$ (m, 1H), 3.13 (ddd, $J=16.8,7.1,4.3 \mathrm{~Hz}, 0.5 \mathrm{H}), 2.91-2.79(\mathrm{~m}, 1.5 \mathrm{H}), 2.72-2.60(\mathrm{~m}, 0.5 \mathrm{H})$, 2.57-2.47 (m, 0.5H), 2.39-2.22 (m, 1H), $2.19(\mathrm{~s}, 1.5 \mathrm{H}), 2.16(\mathrm{~s}, 1.5 \mathrm{H}), 2.15-1.74(\mathrm{~m}, 2 \mathrm{H})$, $1.63-1.50(\mathrm{~m}, 0.5 \mathrm{H}), 1.45-1.36(\mathrm{~m}, 0.5 \mathrm{H}) .{ }^{13} \mathrm{C} \mathrm{NMR}\left(75 \mathrm{MHz}, \mathrm{CDCl}_{3}\right) \delta 199.9,199.8,195.6$, $195.0,163.3,163.2,146.7,146.6,143.1,142.9,136.8,136.8,129.8,129.0,129.0,128.1$, $128.0,127.98,127.0,126.9,126.2,113.8,113.3,113.1,113.0,112.3,110.2,108.3,57.9$, 
$57.8,55.4,43.9,42.7,38.1,37.7,29.2,28.9,28.3,28.1,27.7,27.0,24.7,24.5$. HRMS $\left._{(E S I}{ }^{+}\right)$ calcd for $[\mathrm{M}+\mathrm{H}]^{+} \mathrm{C}_{26} \mathrm{H}_{28} \mathrm{NO}_{3} \mathrm{~m} / \mathrm{z}$ 402.2069, found 402.2064.

\section{2-((3-acetyl-1-(2-methylbenzyl)-1,4-dihydropyridin-4-yl)methyl)-6-methoxy-3,4-}

dihydronaphthalen-1(2H)-one (1c). Method A: From enamine 4b (140. mg, $1.1 \mathrm{mmol}),( \pm)$ 3b $(266.0 \mathrm{mg}, 1.1 \mathrm{mmol})$. Purification by column chromatography on silica gel (EtOAc gradient in petroleum ether) gave 1c as a yellow oil (269.6 mg, 59\%). Method B: From enamine $4 \mathrm{~b}$ (94.6 mg, $0.50 \mathrm{mmol}),( \pm)-3 b(122.0 \mathrm{mg}, 0.50 \mathrm{mmol})$ and $(S)-\mathrm{III}(20 \mathrm{~mol} \%)$. Purification by column chromatography on silica gel (EtOAc gradient in petroleum ether) gave the enantio-enriched DHP 1c (207.6 mg, 55\%). HPLC Chiralpak ${ }^{\circledR}$ IA-3 column; 90/10 heptane/(isopropanol/ethanol $=1: 1)$; flow rate $=1.5 \mathrm{~mL} \cdot \mathrm{min}^{-1} ; \mathrm{t}_{1}=19.94 \mathrm{~min}$ (minor), $\mathrm{t}_{2}=$ $23.1 \mathrm{~min}$ (minor), $\mathrm{t}_{3}=26.8 \mathrm{~min}$ (major), $\mathrm{t}_{4}=37.6 \mathrm{~min}$ (major); $d r=52: 48 ;$ er major $=92: 8$; er minor $=95: 5 .{ }^{1} \mathrm{H}$ NMR $\left(300 \mathrm{MHz}, \mathrm{CDCl}_{3}\right) \delta$ 7.97-7.91 (m, $\left.1 \mathrm{H}\right), 7.25-7.03(\mathrm{~m}, 5 \mathrm{H}), 6.79-6.75$ (m, 1H), 6.67-6.64 (m, 1H), 5.91-5.86 (m, 1H), 5.05-5.00 (m, 1H), $4.43(\mathrm{~s}, 1 \mathrm{H}), 4.41(\mathrm{~s}, 1 \mathrm{H})$, $3.83(\mathrm{~s}, 3 \mathrm{H}), 3.70-3.65(\mathrm{~m}, 1 \mathrm{H}), 3.19-3.05(\mathrm{~m}, 0.5 \mathrm{H}), 2.98-2.78(\mathrm{~m}, 1.5 \mathrm{H}), 2.72-2.58(\mathrm{~m}$, $0.5 \mathrm{H}), 2.58-2.44(\mathrm{~m}, 0.5 \mathrm{H}), 2.43-2.25(\mathrm{~m}, 1 \mathrm{H}), 2.28(\mathrm{~s}, 3 \mathrm{H}), 2.15(\mathrm{~s}, 1.5 \mathrm{H}), 2.12(\mathrm{~s}, 1.5 \mathrm{H})$, 2.12-1.98 (m, 1H), 1.92-1.82 (m, 1H), 1.68-1.45 (m, 0.5), 1.43-1.37 (m, 0.5H). ${ }^{13} \mathrm{C}$ NMR $(75$ $\left.\mathrm{MHz}, \mathrm{CDCl}_{3}\right) \delta 199.9,199.7,195.6,195.0,163.3,163.2,146.7,146.6,143.0,142.8,135.9$, $134.5,134.4,130.8,129.7,128.2,128.1,127.9,127.6,126.6,126.5,126.4,126.0,113.8$, $113.4,113.1,113.0,112.4,110.1,108.2,56.0,55.9,55.4,43.9,42.8,38.4,37.9,29.1,28.9$, 28.4, 28.2, 27.7, 27.0, 24.6, 24.4, 19.2. HRMS $\left(E S I^{+}\right)$calcd for $[M+H]^{+} C_{27} \mathrm{H}_{30} \mathrm{NO}_{3} \mathrm{~m} / \mathrm{z}$ 416.2226 found 416.2227 .

\section{2-((3-acetyl-1-phenyl-1,4-dihydropyridin-4-yl)methyl)-6-methoxy-3,4-}

dihydronaphthalen-1(2H)-one (1d). Method A: From enamine 4c (161.4. mg, $1.1 \mathrm{mmol}$ ), ( \pm )-3b (268.2 mg, $1.1 \mathrm{mmol})$. Purification by column chromatography on silica gel (EtOAc gradient in petroleum ether) gave $\mathbf{1 d}$ as a yellow oil $(277.0 \mathrm{mg}, 65 \%)$. Method B: From enamine 4c (80.6 mg, $0.50 \mathrm{mmol}),( \pm)-3 b(122.0 \mathrm{mg}, 0.50 \mathrm{mmol})$ and $(S)-\mathrm{III}(20 \mathrm{~mol} \%)$. Purification by column chromatography on silica gel (EtOAc gradient in petroleum ether) 
gave the enantio-enriched DHP 1d (91.4 mg, 47\%). HPLC Chiralpak ${ }^{\circledR}$ IA-3 column; 80/20 heptane/(isopropanol/ethanol = 1:1); flow rate $=1.0 \mathrm{~mL} \cdot \mathrm{min}^{-1} ; \mathrm{t}_{1}=15.8 \mathrm{~min}$ (major), $\mathrm{t}_{2}=18.0$ $\min \left(\right.$ minor), $\mathrm{t}_{3}=22.6 \min \left(\right.$ major), $\mathrm{t}_{4}=24.6 \min ($ minor); $d r=57: 43 ;$ er major $=89: 11 ;$ er minor $=88: 12 .{ }^{1} \mathrm{H}$ NMR $\left(300 \mathrm{MHz}, \mathrm{CDCl}_{3}\right) \delta 7.96(\mathrm{~d}, J=8.7 \mathrm{~Hz}, 0.5 \mathrm{H}), 7.95(\mathrm{~d}, J=8.7 \mathrm{~Hz}$, $0.5 \mathrm{H}), 7.51(\mathrm{~s}, 0.5 \mathrm{H}), 7.46(\mathrm{~s}, 0.5 \mathrm{H}), 7.40-7.35(\mathrm{~m}, 2 \mathrm{H}), 7.21-7.15(\mathrm{~m}, 3 \mathrm{H}), 6.79-6.75(\mathrm{~m}, 1 \mathrm{H})$, $6.68(\mathrm{~d}, J=2.4 \mathrm{~Hz}, 0.5 \mathrm{H}), 6.65(\mathrm{~d}, J=2.4 \mathrm{~Hz}, 0.5 \mathrm{H}), 6.47-6.41(\mathrm{~m}, 1 \mathrm{H}), 5.21-5.16(\mathrm{~m}, 1 \mathrm{H})$, $3.82(\mathrm{~s}, 1.5 \mathrm{H}), 3.81(\mathrm{~s}, 1.5 \mathrm{H}), 3.76-3.66(\mathrm{~m}, 1 \mathrm{H}), 3.21-3.08(\mathrm{~m}, 0.5 \mathrm{H}), 2.97-2.84(\mathrm{~m}, 1.5 \mathrm{H})$, 2.75-2.64 (m, 0.5H), 2.62-2.51 (m, 0.5H), 2.45-2.18 (m, 3H), $2.26(\mathrm{~s}, 1.5 \mathrm{H}), 2.23(\mathrm{~s}, 1.5 \mathrm{H})$, 1.69-1.57 (m, 0.5H), 1.54-1.40 (m, 0.5H). ${ }^{13} \mathrm{C}$ NMR (75 MHz, $\left.\mathrm{CDCl}_{3}\right) \delta 199.8,199.6,196.2$, $195.6,163.4,163.3,146.6,146.5,143.8,140.0139 .9,129.9,129.8,126.6,126.3,126.2$, $126.0,125.4,125.3,120.1,120.0,116.7,116.5,113.2,113.0,112.4,111.4,109.6,55.4$, $\left.44.0,43.0,38.3,37.9,29.2,28.9,28.5,28.3,27.8,27.1,24.9,24.7 . \mathrm{HRMS}_{(\mathrm{ESI}}{ }^{+}\right)$calcd for $[\mathrm{M}+\mathrm{H}]^{+} \mathrm{C}_{25} \mathrm{H}_{26} \mathrm{NO}_{3} \mathrm{~m} / \mathrm{z} 388.1913$, found 388.1907.

\section{2-((3-acetyl-1-propyl-1,4-dihydropyridin-4-yl)methyl)-6-methoxy-3,4-}

dihydronaphthalen-1(2H)-one (1e). Method A: From enamine 4d (63.6 mg, $0.5 \mathrm{mmol}),( \pm)-$ 3b $(122.0 \mathrm{mg}, 0.5 \mathrm{mmol})$. Purification by column chromatography on silica gel (EtOAc gradient in petroleum ether) gave $1 \mathrm{e}$ as a yellow oil $(79.6 \mathrm{mg}, 45 \%)$. Method B: From enamine 4d (104.3 mg, $0.82 \mathrm{mmol}),( \pm)-3 b(200.0 \mathrm{mg}, 0.82 \mathrm{mmol})$ and $(S)-$ III $(20 \mathrm{~mol} \%)$. Purification by column chromatography on silica gel (EtOAc gradient in petroleum ether) gave the enantio-enriched DHP 1e (188.3 mg, 65\%). HPLC Chiralpak ${ }^{\circledR}$ IB column; 80/20 heptane/isopropanol; flow rate $=1.0 \mathrm{~mL} \cdot \mathrm{min}^{-1} ; \mathrm{t}_{1}=8.8 \mathrm{~min}$ (major), $\mathrm{t}_{2}=10.8 \mathrm{~min}$ (minor), $\mathrm{t}_{3}=$ $11.4 \mathrm{~min}$ (major), $\mathrm{t}_{4}=12.3 \mathrm{~min}$ (minor); $d r=55: 45$, er major $=92: 8$; er $\operatorname{minor}=91: 9 .{ }^{1} \mathrm{H} \mathrm{NMR}$ $\left(300 \mathrm{MHz}, \mathrm{CDCl}_{3}\right) \delta 7.96(\mathrm{~d}, J=8.7 \mathrm{~Hz}, 0.5 \mathrm{H}), 7.93(\mathrm{~d}, J=8.7 \mathrm{~Hz}, 0.5 \mathrm{H}), 7.07$ (s, 0.5H), 7.01 (s, 0.5H), 6.78-6.75 (m, 1H), 6.67-6.64 (m, 1H), 5.91-5.86 (m, 1H), 5.07-4.90 (m, 1H), 3.81 (s, 3H), 3.70-3.48 (m, 1H), 3.31-3.01 (m, 2.5H), $2.89(\mathrm{~m}, 1.5 \mathrm{H}), 2.70-2.58(\mathrm{~m}, 0.5 \mathrm{H}), 2.52-$ $2.38(\mathrm{~m}, 1 \mathrm{H}), 2.28-2.23(\mathrm{~m}, 0.5 \mathrm{H}), 2.18(\mathrm{~s}, 1.5 \mathrm{H}), 2.15(\mathrm{~s}, 1.5 \mathrm{H}), 2.09-1.94(\mathrm{~m}, 1 \mathrm{H}), 1.81-1.73$ $(\mathrm{m}, 1 \mathrm{H}), 1.68-1.48(\mathrm{~m}, 2.5 \mathrm{H}), 1.34-1.28(\mathrm{~m}, 0.5 \mathrm{H}), 0.92(\mathrm{t}, J=7.3 \mathrm{~Hz}, 3 \mathrm{H}) .{ }^{13} \mathrm{C}$ NMR $(75$ 
$\left.\mathrm{MHz}, \mathrm{CDCl}_{3}\right) \delta 200.1,199.9,195.4,194.8,163.4,163.3,146.8,146.7,143.0,142.9,129.8$, $127.9,127.7,126.3,126.1,113.2,113.0,112.5,112.4,109.9,108.0,56.4,55.5,43.9,42.8$, 38.3, 37.8, 29.1, 29.0, 28.2, 28.1, 27.6, 26.9, 24.7, 24.5, 23.6, 23.5, 11.0. HRMS (ESI $\left.{ }^{+}\right)$calcd for $[\mathrm{M}+\mathrm{H}]^{+} \mathrm{C}_{22} \mathrm{H}_{28} \mathrm{NO}_{3} \mathrm{~m} / \mathrm{z} 354.2069$, found 354.2069.

\section{2-((3-acetyl-1-benzyl-4H-pyridin-4-yl)methyl)-5,6-dimethoxy-2,3-dihydro-1H-inden-1-one}

(1f). Method A: From enamine 4a (84.1 mg, $0.48 \mathrm{mmol}),( \pm)-3 \mathrm{c}(122.3 \mathrm{mg}, 0.47 \mathrm{mmol})$. Purification by column chromatography on silica gel (EtOAc gradient in petroleum ether) gave $1 \mathrm{f}$ as a yellow oil (107.9 mg, 55\%). Method B: From enamine 4a (175.2 mg, $1.0 \mathrm{mmol}$ ), ( \pm )-3c (260.1 mg, $1.0 \mathrm{mmol})$ and $(S)-$ III $(20 \mathrm{~mol} \%)$. Purification by column chromatography on silica gel (EtOAc gradient in petroleum ether) gave the enantio-enriched DHP 1f $(233.7 \mathrm{mg}$, 56\%). HPLC Chiralpak ${ }^{\circledR}$ IC column; 40/50/10 heptane/DCM/isopropanol; flow rate $=1.0$ $\mathrm{mL} \cdot \mathrm{min}^{-1} ; \mathrm{t}_{1}=9.4 \min$ (major), $\mathrm{t}_{2}=15.2 \mathrm{~min}$ (minor), $\mathrm{t}_{3}=16.9 \min$ (major), $\mathrm{t}_{4}=19.2 \mathrm{~min}$ (minor); $d r=53: 47$; er major = 89:11; er minor = 90:10. ${ }^{1} \mathrm{H}$ NMR $\left(300 \mathrm{MHz}, \mathrm{CDCl}_{3}\right) \delta 7.44-$ $7.11(\mathrm{~m}, 7 \mathrm{H}), 6.88(\mathrm{~s}, 0.5 \mathrm{H}), 6.84(\mathrm{~s}, 0.5 \mathrm{H}), 6.01-5.91(\mathrm{~m}, 1 \mathrm{H}), 5.12(\mathrm{dd}, J=7.6,5.2 \mathrm{~Hz}$, $0.5 \mathrm{H}), 4.95(\mathrm{dd}, J=7.6,5.5 \mathrm{~Hz}, 0.5 \mathrm{H}), 4.47(\mathrm{~s}, 2 \mathrm{H}), 3.96(\mathrm{~s}, 3 \mathrm{H}), 3.90(\mathrm{~s}, 3 \mathrm{H}), 3.78-3.71(\mathrm{~m}$, 0.5H), 3.68-3.64 (m, 0.5H), 3.33-3.02 (m, 1.5H), 2.85-2.61 (m, 1.5H), $2.22(\mathrm{~s}, 1.5 \mathrm{H}), 2.17(\mathrm{~s}$, 1.5H), 2.00-1.88 (m, 1H), 1.58-1.36 (m, 1H). ${ }^{13} \mathrm{C}$ NMR (75 MHz, $\left.\mathrm{CDCl}_{3}\right) \delta$ 208.5, 208.3, 195.5, $194.95,155.5,155.4,149.7,149.4,143.3,142.8,136.8,129.5,129.2,129.1,128.3,128.2$, $127.1,127.0,114.0,113.3,110.1,108.5,107.7,107.5,104.4,104.3,58.0,57.9,56.3,56.2$, 45.2, 44.2, 41.2, 40.4, 34.0, 32.7, 29.8, 29.4, 24.7, 24.6. HRMS $\left(\mathrm{ESI}^{+}\right)$calcd for $[\mathrm{M}+\mathrm{H}]^{+}$ $\mathrm{C}_{26} \mathrm{H}_{28} \mathrm{NO}_{4} \mathrm{~m} / \mathrm{z}$ 418.2018, found 418.2021.

Methyl 4-((5,6-dimethoxy-1-oxo-2,3-dihydro-1H-inden-2-yl)methyl)-1-(2-methylbenzyl)1,4-dihydropyridine-3-carboxylate (1g). Method A: From enamine 4f (133.4 mg, 0.65 $\mathrm{mmol}),( \pm)-3 \mathrm{c}(161.0 \mathrm{mg}, 0.62 \mathrm{mmol})$. Purification by column chromatography on silica gel (EtOAc gradient in petroleum ether) gave $\mathbf{1 g}$ as a yellow oil (304.3 mg, 68\%). Method B: From enamine $\mathbf{4 f}(98.5 \mathrm{mg}, 0.48 \mathrm{mmol}),( \pm)-3 \mathrm{c}(125.1 \mathrm{mg}, 0.48 \mathrm{mmol})$ and $(S)-\mathrm{III}(20 \mathrm{~mol} \%)$. Purification by column chromatography on silica gel (EtOAc gradient in petroleum ether) 
gave the enantio-enriched DHP $1 \mathrm{~g}$ (124.6 mg, 58\%). HPLC Chiralpak ${ }^{\circledR}$ IA-3 column; 80/20 heptane/(isopropanol/ethanol $=1: 1)$; flow rate $=1.0 \mathrm{~mL} \cdot \mathrm{min}^{-1} ; \mathrm{t}_{1}=16.6 \mathrm{~min}$ (major), $\mathrm{t}_{2}=19.2$ $\min \left(\right.$ minor),$t_{3}=24.1$ min (major), $t_{4}=26.0 \min$ (minor); $d r=51: 49 ;$ er major = 92:8; er minor $=92: 8 .{ }^{1} \mathrm{H}$ NMR $\left(300 \mathrm{MHz}, \mathrm{CDCl}_{3}\right) \delta 7.28-7.16(\mathrm{~m}, 6 \mathrm{H}), 6.87(\mathrm{~s}, 0.55 \mathrm{H}), 6.85(\mathrm{~s}, 0.45 \mathrm{H})$, 5.96-5.86 (m, 1H), $5.01(\mathrm{dd}, J=7.8,5.1 \mathrm{~Hz}, 0.55 \mathrm{H}), 4.84(\mathrm{dd}, J=7.5,5.1 \mathrm{~Hz}, 0.45 \mathrm{H}), 4.40$ (s, 1.1H), $4.39(\mathrm{~s}, 0.9 \mathrm{H}), 3.98(\mathrm{~s}, 3 \mathrm{H}), 3.90(\mathrm{~s}, 3 \mathrm{H}), 3.70(\mathrm{~s}, 1.35 \mathrm{H}), 3.67(\mathrm{~s}, 1.65 \mathrm{H}), 3.55-3.49$ $(\mathrm{m}, 0.45 \mathrm{H}), 3.33-3.18(\mathrm{~m}, 1.55 \mathrm{H}), 3.01-2.72(\mathrm{~m}, 2 \mathrm{H}), 2.31(\mathrm{~s}, 1.65 \mathrm{H}), 2.30(\mathrm{~s}, 1.35 \mathrm{H}), 2.13-$ $1.98(\mathrm{~m}, 1 \mathrm{H}), 1.64-1.45(\mathrm{~m}, 1 \mathrm{H}) .{ }^{13} \mathrm{C} \operatorname{NMR}\left(75 \mathrm{MHz}, \mathrm{CDCl}_{3}\right) \delta 208.4,208.2,168.9,168.5$, $155.5,155.4,149.6,149.5,149.4,149.3,142.0,141.5,136.2,136.1,134.8,134.7,130.8$, $129.5,128.8,128.5,128.1,127.8,126.5,108.2,107.6,107.5,106.7,104.4,101.6,101.3$, $56.3,56.2,51.1,51.0,45.1,44.1,41.8,40.5,34.3,32.8,30.8,30.6,29.8,19.3,19.2$. HRMS $\left(E S I^{+}\right)$calcd for $[\mathrm{M}+\mathrm{H}]^{+} \mathrm{C}_{27} \mathrm{H}_{30} \mathrm{NO}_{5} \mathrm{~m} / \mathrm{z} 448.2124$, found 448.2111.

\section{1-benzyl-4-((5,6-dimethoxy-1-oxo-2,3-dihydro-1H-inden-2-yl)methyl)-1,4-}

dihydropyridine-3-carbonitrile (1h). Method B: From enamine $4 f(77.5 \mathrm{mg}, 0.49 \mathrm{mmol})$, ( \pm )-3c (128.0 mg, $0.49 \mathrm{mmol})$ and $(S)$-III (20 mol\%) (or $(R)-$ III). Purification by column chromatography on silica gel (EtOAc gradient in petroleum ether) gave the enantio-enriched DHP $1 \mathrm{~h}$ as a yellow oil (105.9 mg, 54\%). HPLC Chiralpak ${ }^{\circledR}$ IE column; 60/33/7 heptane/DCM/isopropanol; flow rate $=1 \mathrm{~mL} \cdot \mathrm{min}^{-1} ; \mathrm{t}_{1}=15.4 \mathrm{~min}$ (major), $\mathrm{t}_{2}=17.5 \mathrm{~min}$ (minor), $\mathrm{t}_{3}=20.1 \mathrm{~min}$ (major), $\mathrm{t}_{4}=21.8 \mathrm{~min}$ (minor); With $(S)$-III : $d r=50: 40 ;$ er major = 88:12; er minor $=94: 6$; With $(R)-$ III $: d r=55: 45$; er major $=85: 15$; er minor $=85: 15 .{ }^{1} \mathrm{H}$ NMR $(300$ $\left.\mathrm{MHz}, \mathrm{CDCl}_{3}\right) \delta$ 7.53-7.24 (m, 6H), $6.96(\mathrm{~s}, 1 \mathrm{H}), 6.78(\mathrm{~m}, 1 \mathrm{H}), 5.98(\mathrm{~m}, 1 \mathrm{H}), 4.94(\mathrm{dd}, J=8.1$, $4.4 \mathrm{~Hz}, 0.5 \mathrm{H}$ ), $4.84(\mathrm{dd}, J=8.0,4.4 \mathrm{~Hz}, 0.5 \mathrm{H}), 4.43(\mathrm{~s}, 1 \mathrm{H}), 4.42(\mathrm{~s}, 1 \mathrm{H}), 4.06(\mathrm{~s}, 3 \mathrm{H}), 4.00$ (s, 3H), 3.64-3.57 (m, 0.5H), 3.47-3.30 (m, 1.5H), 3.13-2.82 (m, 2H), 2.40-2.21 (m, 1H), 1.80$1.65(\mathrm{~m}, 1 \mathrm{H}) .{ }^{13} \mathrm{C}$ NMR $\left(75 \mathrm{MHz}, \mathrm{CDCl}_{3}\right) \delta 207.6,207.2,155.6,155.5,149.6,149.5,149.3$, $148.9,143.4,143.0,136.3,136.2,129.2,129.1,128.9,128.4,128.3,128.3,127.2,127.1$, $121.6,121.2,107.5,107.4,106.2,105.0,104.4,104.3,82.9,82.5,57.6,57.5,56.4,56.2$, 
44.3, 43.7, 41.5, 40.0, 33.8, 33.1, 32.2, 32.1, 29.7. HRMS $\left(\mathrm{ESI}^{+}\right)$calcd for $[\mathrm{M}+\mathrm{H}]^{+} \mathrm{C}_{25} \mathrm{H}_{25} \mathrm{~N}_{2} \mathrm{O}_{3}$ $m / z$ 401.1865, found 401.1852.

\section{1-benzyl-4-((6-methoxy-1-oxo-1,2,3,4-tetrahydronaphthalen-2-yl)methyl)-1,4-}

dihydropyridine-3-carbonitrile (1i). Method B: From enamine $4 f(79.1 \mathrm{mg}, 0.5 \mathrm{mmol}),( \pm)$ 3b (122.1 mg, $0.5 \mathrm{mmol})$ and $(S)$-III (20 mol\%) (or (R)-III (20 mol\%)). Purification by column chromatography on silica gel (EtOAc gradient in petroleum ether) gave the enantio-enriched DHP 1i as a yellow oil (101.0 mg, 52\%). HPLC Chiralpak ${ }^{\circledR}$ IE column; 60/33/7 heptane/DCM/isopropanol; flow rate $=1 \mathrm{~mL} \cdot \mathrm{min}^{-1} ; \mathrm{t}_{1}=12.7 \mathrm{~min}$ (major), $\mathrm{t}_{2}=13.9 \mathrm{~min}$ (major), $\mathrm{t}_{3}=16.4 \mathrm{~min}$ (minor), $\mathrm{t}_{4}=17.5 \mathrm{~min}$ (minor); With $(S)$-III : $d r=55: 45$; er major = 87:13; er minor $=90: 10 ;$ With $(R)-$ III $: d r=58: 42 ;$ er major $=86: 14 ;$ er minor $=89: 11 .{ }^{1} \mathrm{H}$ NMR $(300$ $\left.\mathrm{MHz}, \mathrm{CDCl}_{3}\right) \delta 7.99(\mathrm{~d}, J=2.9 \mathrm{~Hz}, 0.5 \mathrm{H}), 7.96(\mathrm{~d}, J=3.0 \mathrm{~Hz}, 0.5 \mathrm{H}), 7.39-7.29(\mathrm{~m}, 3 \mathrm{H}), 7.21-$ $7.15(\mathrm{~m}, 2 \mathrm{H}), 6.83-6.79(\mathrm{~m}, 1 \mathrm{H}), 6.70-6.62(\mathrm{~m}, 2 \mathrm{H})$, 5.88-5.79 $(\mathrm{m}, 1 \mathrm{H}), 4.81-4.77(\mathrm{~m}, 1 \mathrm{H})$, $4.31(\mathrm{~s}, 1 \mathrm{H}), 4.30(\mathrm{~s}, 1 \mathrm{H}), 3.85(\mathrm{~s}, 1.5 \mathrm{H}), 3.84(\mathrm{~s}, 1.5 \mathrm{H}), 3.47-3.30(\mathrm{~m}, 1 \mathrm{H}), 3.00-2.89(\mathrm{~m}$, $2 \mathrm{H}), 2.88-2.76(\mathrm{~m}, 0.5 \mathrm{H}), 2.72-2.62(\mathrm{~m}, 0.5 \mathrm{H}), 2.40-2.15(\mathrm{~m}, 2 \mathrm{H}), 1.96-1.80(1 \mathrm{H}), 1.69-1.47$ $(\mathrm{m}, 1 \mathrm{H}) .{ }^{13} \mathrm{C}$ NMR $\left(75 \mathrm{MHz}, \mathrm{CDCl}_{3}\right) \delta 198.9,198.8,163.5,163.4,146.4,146.3,143.3,142.9$, $136.4,129.9,129.1,129.0,128.3,128.2,127.1,113.3,113.2,112.4,106.4,105.3,82.9$, $82.2,57.5,57.4,55.5,43.1,43.0,39.3,38.2,31.2,31.1,31.0,29.4,29.0,28.6,28.4$. HRMS $\left(\mathrm{ESI}^{+}\right)$calcd for $[\mathrm{M}+\mathrm{H}]^{+} \mathrm{C}_{25} \mathrm{H}_{25} \mathrm{~N}_{2} \mathrm{O}_{2} \mathrm{~m} / \mathrm{z} 385.1916$, found 385.1917 .

Allyl (6,7-dimethoxy-3,4-dihydronaphthalen-1-yl) carbonate (6). To a solution of KHMDS (1.0 M solution in THF, $1.5 \mathrm{~g}, 5.82 \mathrm{mmol})$ and TMEDA $(0.88 \mathrm{~mL}, 5.82 \mathrm{mmol})$ cooled at $-78{ }^{\circ} \mathrm{C}$ was added dropwise a solution of 6,7-dimethoxy-1-tetralone 2a $(1.0 \mathrm{~g}, 4.85 \mathrm{mmol})$ in $10 \mathrm{~mL}$ of dry THF over a period of 30 minutes. The mixture was stirred at this temperature for 1 hour, and then was diluted with $10 \mathrm{~mL}$ of dry THF. When the temperature was settled at -78 ${ }^{\circ} \mathrm{C}$, allyl chloroformate $(0.62 \mathrm{~mL}, 6.64 \mathrm{mmol})$ was added slowly over the slurry and left to stir for 30 minutes. The reaction was quenched with saturated aqueous $\mathrm{NH}_{4} \mathrm{Cl}$, then extracted 3 times with diethyl ether. The combined extracts were dried over $\mathrm{MgSO}_{4}$ and concentrated in vacuum. The crude residue was purified by column chromatography on silica gel (Petroleum 
ether/EtOAc $=3: 1)$ to give the title enol carbonate 6 as a colorless oil $(1.0 \mathrm{~g}, 71 \%) .{ }^{1} \mathrm{H}$ NMR (300 MHz, $\left.\mathrm{CDCl}_{3}\right) \delta 6.74(\mathrm{~s}, 1 \mathrm{H}), 6.69(\mathrm{~s}, 1 \mathrm{H}), 6.03-5.95(\mathrm{~m}, 1 \mathrm{H}), 5.69(\mathrm{t}, J=4.7 \mathrm{~Hz}, 1 \mathrm{H})$, 5.40 (ddd, $J=17.2,2.8,1.4 \mathrm{~Hz}, 1 \mathrm{H}$ ), 5.30 (dd, $J=10.4,1.2 \mathrm{~Hz}, 1 \mathrm{H}), 4.70$ (dt, $J=5.8,1.2 \mathrm{~Hz}$, 2H), $3.86(\mathrm{~s}, 3 \mathrm{H}), 3.83(\mathrm{~s}, 3 \mathrm{H}), 2.78(\mathrm{t}, \mathrm{J}=8.2 \mathrm{~Hz}, 2 \mathrm{H}), 2.47-2.37(\mathrm{~m}, 2 \mathrm{H}) .{ }^{13} \mathrm{C} \mathrm{NMR}(75 \mathrm{MHz}$, $\left.\mathrm{CDCl}_{3}\right) \delta 153.4,148.8,147.5,146.0,131.4,129.4,123.0,119.4,112.7,111.5,104.9,69.0$, 56.2, 56.1, 27.2, 22.2. HRMS $\left(E S I^{+}\right)$calcd for $[M+H]^{+} \mathrm{C}_{16} \mathrm{H}_{19} \mathrm{O}_{5} \mathrm{~m} / \mathrm{z}$ 291.1232, found 291.1223.

General procedure for Pd-DAAA: Two oven-dried $5 \mathrm{~mL}$ vials were individually charged with a magnetic stirring bar. One vial was loaded with $\mathrm{Pd}_{2}(\mathrm{dba})_{3} \mathrm{CHCl}_{3}(2.5 \mathrm{~mol} \%)$ and the corresponding chiral Anden Trost ligand (5.5 mol\%); the other one was loaded with the corresponding enol carbonate $6(0.35 \mathrm{mmol})$. The vials were sealed and connected with a transfer cannula. The system flushed with argon, then $1.0 \mathrm{~mL}$ of degassed dry 1,4-dioxane was added to both vials. After stirring for $20 \mathrm{~min}$, the deep red solution containing the catalyst was transferred via cannula into the vial containing the enol carbonate $\mathbf{6}$, and stirring was continued for other 2 hours. The reaction mixture was concentrated in vacuo and the residue was purified by column chromatography on silica gel to afford the title compound. The attribution of the configuration of the novel stereocenter was done in accordance with the literature data.

(R)-2-allyl-6,7-dimethoxy-tetralone-1-one $((\boldsymbol{R})$-5a). From $6(100.0 \mathrm{mg}, 0.35 \mathrm{mmol})$, $\mathrm{Pd}_{2}(\mathrm{dba})_{3} \mathrm{CHCl}_{3}(15 \mathrm{mg}, 2.5 \mathrm{~mol} \%),(R, R)$-Anden Trost ligand $(26.0 \mathrm{mg}, 5.5 \mathrm{~mol} \%)$ and $2 \times 1.0 \mathrm{~mL}$ of degassed dry 1,4-dioxane. Purification by column chromatography on silica gel (Petroleum ether $/$ EtOAc $=49: 1)$ afforded the title compound $(77.0 \mathrm{mg}, 94 \%)$ as yellowish oil . Spectral data $\left({ }^{1} \mathrm{H}\right.$ and ${ }^{13} \mathrm{C}$ NMR) were identical to the racemic compound. HPLC (Chiralpak ${ }^{\circledR}$ IC column; 95:5 Heptane / Isopropanol; flow rate $=1 \mathrm{~mL} \cdot \mathrm{min}^{-1} ; \mathrm{t}_{1}=16.44 \mathrm{~min}$ (minor), $\mathrm{t}_{2}=$ $19.49 \mathrm{~min}$ (major), $96 \%$ ee).

(S)-2-allyl-6,7-dimethoxy-tetralone-1-one ((S)-5a). From 6 (300.0 mg, 1.03 mmol), $\mathrm{Pd}_{2}(\mathrm{dba})_{3} \mathrm{CHCl}_{3}(45.0 \mathrm{mg}, 2.5 \mathrm{~mol} \%)(S, S)$-Anden Trost ligand $(78.0 \mathrm{mg}, 5.5 \mathrm{~mol} \%)$ and $2 \mathrm{x}$ 
$3 \mathrm{~mL}$ of degassed dry 1,4-dioxane. Purification by column chromatography on silica gel (petroleum ether/EtOAc $=49: 1)$ afforded the title compound $(200.0 \mathrm{mg}, 81 \%)$ as yellowish oil. Spectral data $\left({ }^{1} \mathrm{H}\right.$ and ${ }^{13} \mathrm{C}$ NMR) was identical to the racemic compound. HPLC (Chiralpak ${ }^{\circledR}$ IC column; 95:5 Heptane / Isopropanol; flow rate $=1 \mathrm{~mL} \cdot \mathrm{min}^{-1} ; \mathrm{t}_{1}=16.33 \mathrm{~min}$ (major), $\mathrm{t}_{2}=$ $19.6 \min$ (minor), $90 \%$ ee).

$(R, E)-4-(6,7-d i m e t h o x y-1-o x o-t e t r a l o n-2-y l) b u t-2-e n a l \quad((R)-3 a)$. Following the general procedure for the metathesis reaction, from crotonaldehyde $(91.0 \mathrm{mg}, 1.29 \mathrm{mmol}),(\boldsymbol{R})-5 \mathrm{a}$ (70.0 mg, $0.32 \mathrm{mmol})$, Hoveyda-Grubbs' $2^{\text {nd }}(5 \mathrm{mg}, 2.5 \% \mathrm{~mol})$ and $\mathrm{CH}_{2} \mathrm{Cl}_{2}(3.0 \mathrm{~mL})$. Purification by column chromatography on silica gel (Petroleum ether/EtOAc $=1: 1)$ gave an off-white powder $(76.0 \mathrm{mg}, 96 \%)$. Spectral data $\left({ }^{1} \mathrm{H}\right.$ and $\left.{ }^{13} \mathrm{C} \mathrm{NMR}\right)$ were identical to the racemic compound. HPLC (Chiralpak ${ }^{\circledR}$ IC column, 9:1 MTBE/ isopropanol, flow rate $=1$ $\mathrm{mL} \cdot \mathrm{min}^{-1}, \mathrm{t}_{1}=13.06 \mathrm{~min}$ (minor), $\mathrm{t}_{2}=16.81 \mathrm{~min}$ (major), $95 \%$ ee).

$(S, E)-4-(6,7-d i m e t h o x y-1-o x o-t e t r a l o n-2-y l) b u t-2-e n a l \quad(S)-3 a$. Following the general procedure for the metathesis reaction, from crotonaldehyde $(207.0 \mathrm{mg}, 2.95 \mathrm{mmol}),(S)-5 \mathrm{a}$ (140.0 mg, $0.74 \mathrm{mmol})$, Hoveyda-Grubbs' $2^{\text {nd }}(10 \mathrm{mg}, 2.5 \% \mathrm{~mol})$ and $\mathrm{CH}_{2} \mathrm{Cl}_{2}(8.0 \mathrm{~mL})$. Purification by column chromatography on silica gel (Petroleum ether/EtOAc $=1: 1)$ gave an off-white powder (150.0 mg, 83\%). Spectral data $\left({ }^{1} \mathrm{H}\right.$ and ${ }^{13} \mathrm{C}$ NMR) were identical to the racemic compound. HPLC: Chiralpak $^{\circledR}$ IC column, 9:1 MTBE/ isopropanol, flow rate = 1 $\mathrm{mL} \cdot \mathrm{min}^{-1}, \mathrm{t}_{1}=12.93 \mathrm{~min}$ (major), $\mathrm{t}_{2}=16.91 \mathrm{~min}$ (minor), $90 \%$ ee).

\section{$(R)-2-(((R)-1-b e n z y l-3-($ prop-1-en-2-yl)-1,4-dihydropyridin-4-yl)methyl)-6,7-dimethoxy-}

\section{3,4-dihydronaphthalen-1(2H)-one $((R, R)-1 \mathrm{a})$}

Following the general procedure for the synthesis of 1,4-DHPs by enantioselective aminocatalysis (Method B). From enal $(R)-3 a(50 \mathrm{mg}, 0.18 \mathrm{mmol})$, saccharin (14 mg, 0.073 mmol, 40\%), (S)-Jørgensen catalyst III (22 mg, $0.036 \mathrm{mmol})$ and enamine 4a (32 mg, 0.18 $\mathrm{mmol})$ and dichloroethane $(0.8 \mathrm{~mL})$. Purification by chromatography on silica gel (Petroleum ether/ EtOAc $=1: 1)$ gave 1,4-DHP $(R, R)-1 \mathrm{a}(50 \mathrm{mg}, 64 \%)$ as a light-yellow oil. $[\alpha]_{\mathrm{D}}{ }^{25}-207.4$ (c $\left.0.43 \mathrm{CHCl}_{3}\right) .{ }^{1} \mathrm{H}$ NMR $\left(300 \mathrm{MHz}, \mathrm{CDCl}_{3}\right) \delta 7.47(\mathrm{~d}, J=4.7 \mathrm{~Hz}, 1 \mathrm{H}), 7.38-7.18(\mathrm{~m}, 6 \mathrm{H})$, 
$6.62(\mathrm{~s}, 1 \mathrm{H}), 5.93(\mathrm{~d}, J=5.5 \mathrm{~Hz}, 1 \mathrm{H}), 5.03(\mathrm{dd}, J=7.6,5.5 \mathrm{~Hz}, 1 \mathrm{H}), 4.46(\mathrm{~s}, 2 \mathrm{H}), 3.92(\mathrm{~s}$, 3H), 3.89 (s, 3H), 3.72-3.69 (dd, $J=12.0,5.6 \mathrm{~Hz}, 1 \mathrm{H}), 2.87(\mathrm{t}, J=6.0 \mathrm{~Hz}, 2 \mathrm{H}), 2.60-2.42(\mathrm{~m}$, 1H), 2.42-2.29 (m, 1H), $2.18(\mathrm{~s}, 3 \mathrm{H}), 2.14-2.05(\mathrm{~m}, 1 \mathrm{H}), 1.89-1.78(\mathrm{~m}, 1 \mathrm{H}), 1.45-1.19(\mathrm{~m}$, 1H). ${ }^{13} \mathrm{C}$ NMR $\left(75 \mathrm{MHz}, \mathrm{CDCl}_{3}\right) \delta 199.9,195.7,153.2,147.8,143.1,138.9,136.9,129.1$, $128.1,128.0,127.1,125.8,113.5,110.3,110.2,108.8,58.0,56.2,56.1,43.55,38.3,29.6$, 28.5, 28.4, 24.8. SFC analytic separation: Chiralpak ${ }^{\circledR}$ IA column; 30\% Ethanol/Isopropanol (70:30), flow rate $=4 \mathrm{~mL} \cdot \mathrm{min}^{-1} ; \mathrm{t}_{R, R}=4.92 \mathrm{~min} ; d r=93: 7 ;$ er $=98: 2$.

\section{(S)-2-(((S)-1-benzyl-3-(prop-1-en-2-yl)-1,4-dihydropyridin-4-yl)methyl)-6,7-dimethoxy-}

\section{3,4-dihydronaphthalen-1(2H)-one ((S,S)-1a)}

From enal (S)-3a (50 mg, $0.18 \mathrm{mmol}$, ee 94\%), saccharin (14 mg, $0.073 \mathrm{mmol}, 40 \%),(R)$ Jørgensen catalyst III (22 mg, $0.036 \mathrm{mmol})$ and enamine $4 \mathrm{a}$ (32 mg, $0.18 \mathrm{mmol}$ ) and dichloroethane $(0.8 \mathrm{~mL})$. Purification by chromatography on silica gel (Petroleum ether/ EtOAc $=1: 1)$ gave 1,4-dihydropyridine $(S, S)$-1a $(38 \mathrm{mg}, 48 \%)$ as a light-brown oil. $[\alpha]_{D}{ }^{25}$ +214.4 (c $\left.0.43 \mathrm{CHCl}_{3}\right)$. Spectral data $\left({ }^{1} \mathrm{H}\right.$ and $\left.{ }^{13} \mathrm{C} \mathrm{NMR}\right)$ were identical to the compound $(R, R)-1 a$. SFC analytic separation: Chiralpak ${ }^{\circledR}$ IA column; 30\% Ethanol/Isopropanol (70:30), flow rate $=4 \mathrm{~mL} \cdot \mathrm{min}^{-1} ; \mathrm{t}_{\mathrm{S}, \mathrm{S}}=5.22 \mathrm{~min} ; d r=92: 8 ; \mathrm{er}=99.5: 0.5$.

\section{(S)-2-(((R)-1-benzyl-3-(prop-1-en-2-yl)-1,4-dihydropyridin-4-yl)methyl)-6,7-dimethoxy-}

\section{3,4-dihydronaphthalen-1(2H)-one $((S, R)-1 \mathrm{a})$}

From enal (S)-3a (50 mg, $0.18 \mathrm{mmol}$, ee 98\%), saccharin (14 mg, $0.073 \mathrm{mmol}, 40 \%)$, (S)Jørgensen catalyst III (22 mg, $0.036 \mathrm{mmol}$ ) and enamine $4 \mathrm{a}$ (32 mg, $0.18 \mathrm{mmol}$ ) and dichloroethane $(0.8 \mathrm{~mL})$. Purification by chromatography on silica gel (Petroleum ether/EtOAc $=1: 1)$ gave 1,4-DHP $(S, R)-1 \mathrm{a}(46 \mathrm{mg}, 59 \%)$ as a yellow oil. $[\alpha]_{D}{ }^{25}-203.7(c 0.43$ $\left.\mathrm{CHCl}_{3}\right) .{ }^{1} \mathrm{H}$ NMR $\left(300 \mathrm{MHz}, \mathrm{CDCl}_{3}\right) \delta 7.47(\mathrm{~s}, 1 \mathrm{H}), 7.39-7.08(\mathrm{~m}, 6 \mathrm{H}), 6.65(\mathrm{~s}, 1 \mathrm{H}), 5.91$ (d, J $=6.9 \mathrm{~Hz}, 1 \mathrm{H}), 5.03(\mathrm{dd}, J=7.7,5.2 \mathrm{~Hz}, 1 \mathrm{H}), 4.44(\mathrm{~s}, 2 \mathrm{H}), 3.91(\mathrm{~s}, 3 \mathrm{H}), 3.87(\mathrm{~s}, 3 \mathrm{H}), 3.70-$ $3.58(\mathrm{~m}, 1 \mathrm{H}), 3.1-3.07(\mathrm{~m}, 1 \mathrm{H}), 2.85-2.79(\mathrm{~m}, 1 \mathrm{H}), 2.69-2.61(\mathrm{~m}, 1 \mathrm{H}), 2.32-2.23(\mathrm{~m}, 1 \mathrm{H}), 2.15$ $(\mathrm{s}, 3 \mathrm{H}), 2.12-1.98(\mathrm{~m}, 1 \mathrm{H}), 1.89-1.80(\mathrm{~m}, 1 \mathrm{H}), 1.53-1.63(\mathrm{~m}, 1 \mathrm{H}) .{ }^{13} \mathrm{C} \mathrm{NMR}\left(75 \mathrm{MHz}, \mathrm{CDCl}_{3}\right) \delta$ 200.2 , 195.1, 153.3, 147.8, 142.9, 139.1, 136.8, 129.1, 128.2, 128.1, 127.0, 125.5, 114.0, 
$110.3,108.8,108.4,57.9,56.1,56.0,42.5,37.8,28.3,27.3,27.0,24.6$. SFC analytic separation: Chiralpak ${ }^{\circledR}$ IA column; 30\% Ethanol/Isopropanol (70:30), flow rate $=4 \mathrm{~mL} \cdot \mathrm{min}^{-1}$; $\mathrm{t}_{S, R}=6.08 \mathrm{~min} ; d r=90: 10 ; \mathrm{er}=99.5: 0.5$.

\title{
(R)-2-(((S)-1-benzyl-3-(prop-1-en-2-yl)-1,4-dihydropyridin-4-yl)methyl)-6,7-dimethoxy-
}

\section{3,4-dihydronaphthalen-1(2H)-one $((R, S)-1 \mathrm{a})$}

From enal (R)-3a (5 mg, $0.18 \mathrm{mmol})$, saccharin (14 mg, $0.073 \mathrm{mmol}, 40 \%)$, (R)-Jørgensen catalyst III (22 mg, $0.036 \mathrm{mmol})$ and enamine $4 \mathrm{a}(32 \mathrm{mg}, 0.18 \mathrm{mmol})$ and dichloroethane $(0.8$ $\mathrm{mL}$ ). Purification by chromatography on silica gel (petroleum ether/EtOAc $=1: 1$ ) gave $1,4-$ $\operatorname{DHP}(R, S)-1 \mathrm{a}(33 \mathrm{mg}, 42 \%)$ as a yellow oil. $[\alpha]_{\mathrm{D}}{ }^{25}+198.3\left(\mathrm{c} 0.43 \mathrm{CHCl}_{3}\right)$. Spectral data $\left({ }^{1} \mathrm{H}\right.$ and ${ }^{13} \mathrm{C}$ NMR) were identical to the compound $(S, R)-1 \mathbf{a}$. SFC analytic separation: Chiralpak ${ }^{\circledR}$ IA column; 30\% Ethanol/Isopropanol (70:30), flow rate $=4 \mathrm{~mL} \cdot \mathrm{min}^{-1} ; \mathrm{t}_{R, S}=10.0 \mathrm{~min} ; \mathrm{dr}=$ 91:9; er = 99:1.

\author{
AUTHOR INFORMATION \\ Corresponding Authors: \\ *E-mail:vgembus@vfp-therapies.com. \\ *E-mail: vincent.levacher@insa-rouen.fr. \\ ORCID: \\ Vincent Gembus: 0000-0001-6510-7608 \\ Vincent Levacher: 0000-0002-6429-1965 \\ Notes
}

The authors declare no competing financial interest.

\section{ASSOCIATED CONTENT}


Supporting Information: Copies of ${ }^{1} \mathrm{H}$ and ${ }^{13} \mathrm{C}\left\{{ }^{1} \mathrm{H}\right\}$ NMR spectra, HPLC and SFC chromatograms. This material is available free of charge via the Internet at http://pubs.acs.org.

\section{ACKNOWLEDGMENT}

This work was partly supported by INSA-Rouen, Rouen University, CNRS, Labex SynOrg (ANR-11-LABX-0029), Région Normandie.

\section{REFERENCES}

(1) Sharmaa, V. K.; Singh S. K. Synthesis, Utility and Medicinal Importance of 1,2- \& 1,4Dihydropyridines. RSC Adv. 2017, 7, 2682-2732.

(2) Selected examples: (a) Bodor, N.; Shek, E.; Higuchi, T. Delivery of a Quaternary Pyridinium Salt Across the Blood-Brain Barrier by its Dihydropyridine Derivative. Science 1975, 190, 155-156. (b) Bodor, N.; Simpkins, J. W. Redox Delivery System for Brain Specific, Sustained Release of Dopamine. Science 1983, 221, 65-67. (c) Chen, P.; Bodor, N.; Wu, W.M.; Prokai, L. Strategies to Target Kyotorphin Analogues to the Brain. J. Med. Chem. 1998, $41,3773-3781$.

(3) Selected reviews, see: (a) Bodor, N.; Buchwald, P. Retrometabolic Drug Design: Principles and Recent Developments. Pure Appl. Chem. 2008, 80, 1669-1682. (b) Bodor, N.; Buchwald, P. Recent Advances in Retrometabolic Drug Design (RMDD) and Development. Pharmazie 2010, 65, 395-403. (c) Pop, E. Optimization of the Properties of Brain Specific Chemical Delivery Systems by Structural Modifications. Curr. Med. Chem. 1997, 4, 279-295. (d) Bodor, N.; Buchwald, P. Recent Advances in the Brain Targeting of Neuropharmaceuticals by Chemical Delivery Systems. Advanced Drug Delivery Reviews 1999, 36, 229-254. 
(4) (a) Bohn, P.; Le Fur, N.; Hagues, N.; Costentin, J.; Torquet, N.; Papamicael, C.; Marsais, F.; Levacher, V. Rational Design of Central Selective Acetylcholinesterase Inhibitors by Means of a "Bio-Oxidisable Prodrug" Strategy. Org. Biomol. Chem. 2009, 7, 2612-2618. (b) Bohn, P.; Gourand, F.; Papamicaël, C.; Ibazizène, M.; Dhilly, M.; Gembus, V.; Alix, F.; Ţîntaş, M.-L.; Marsais, F.; Barre, L.; Levacher, V. Dihydroquinoline Carbamate Derivatives as "Bio-Oxidizable" Prodrugs for Brain Delivery of Acetylcholinesterase Inhibitors:

$\left[{ }^{11} \mathrm{C}\right]$ Radiosynthesis and Biological Evaluation. ACS Chem. Neurosci. 2015, 6, 737-744. (c) Gourand, F.; Mercey, G.; Ibazizène, M.; Tirel, O.; Henry, J.; Levacher, V.; Perrio, C.; Barre, L. Chemical Delivery System of Metaiodobenzylguanidine (MIBG) to the Central Nervous System. J. Med. Chem., 2010, 53, 1281-1287. (d) Gourand, F.; Tîntaş, M.-L.; Henry, A.; Ibazizène, M.; Dhilly, M.; Fillesoye, F.; Papamicaël, C.; Levacher, V.; Barre, L. Delivering FLT to the Central Nervous System by Means of a Promising Targeting System: Synthesis, $\left[{ }^{11} \mathrm{C}\right]$ Radiosynthesis, and in Vivo Evaluation. ACS Chem. Neurosci., 2017, 8, 2457-2467 (e) Peauger, L.; Azzouz, R.; Gembus, V.; Tînţaş, M.-L.; Sopková-de Oliveira Santos, J.; Bohn, P.; Papamicaël, C.; Levacher, V. Donepezil-Based Central Acetylcholinesterase Inhibitors by Means of a "Bio-Oxidizable" Prodrug Strategy: Design, Synthesis, and in Vitro Biological Evaluation. J. Med. Chem., 2017, 60, 5909-5926. (f) Azzouz, R.; Peauger, L.; Gembus, V.; Ţînţaş, M.-L.; Sopková-de Oliveira Santos, J.; Papamicaël, C.; Levacher, V. Novel Donepezil-like $\mathrm{N}$-benzylpyridinium Salt Derivatives as AChE Inhibitors and their Corresponding Dihydropyridine "Bio-Oxidizable" Prodrugs: Synthesis, Biological Evaluation and Structure-Activity Relationship. Eur. J. Med. Chem., 2018, 145, 165-190.

(5) Chiral drugs: Chemistry and Biological Action; Lin, G.-H., You, Q.-D., Cheng, J.-F, Eds; Wiley: Hoboken, NJ, 2011.

(6) (a) Yang, J.; Wang, C.; Xie, X.; Li, H.; Li, Y. Acid-Catalyzed Cascade Reactions of Enaminones with Aldehydes: C-H Functionalization To Afford 1,4-Dihydropyridines. Eur. J. Org. Chem. 2010, 4189-4193. (b) Sirijindalert, T.; Hansuthirakul, K.; Rashatasakhon, P.; Sukwattanasinitt, M.; Ajavakom, A. Novel Synthetic Route to 1,4-Dihydropyridines from $\beta$ Amino Acrylates by Using Titanium(IV) Chloride Under Facile Conditions. Tetrahedron 2010, 
66, 5161-5167. (c) Wan, J.-P.; Gan, S.-F.; Sun, G.-L.; Pan, Y.-J. Novel Regioselectivity: Three-Component Cascade Synthesis of Unsymmetrical 1,4- and 1,2-Dihydropyridines. J. Org. Chem. 2009, 74, 2862-2865. (d) Moreau, J.; Duboc, A.; Hubert, C.; Hurvois, J.-P.; Renaud, J.-L. Metal-free Brønsted Acids Catalyzed Synthesis of Functional 1,4Dihydropyridines. Tetrahedron Lett. 2007, 48, 8647-8650. (e) Bartoli, G.; Babiuch, K.; Bosco, M.; Carolone, A.; Galzerano, P.; Melchiorre, P.; Sambri, L. Magnesium Perchlorate as Efficient Lewis Acid: A Simple and Convenient Route to 1,4-Dihydropyridines. Synlett 2007, 2897-2901. (f) Sridharan, V.; Perumal, P. T.; Avendano, C.; Menendez, J. C. A New Threecomponent Domino Synthesis of 1,4-Dihydropyridines. Tetrahedron 2007, 63, 4407-4413. (g) Vohra, R. K.; Bruneau, C.; Renaud, J.-L. Lewis Acid-Catalyzed Sequential Transformations: Straightforward Preparation of Functional Dihydropyridines. Adv. Synth. Catal. 2006, 348, 2571-2574. (h) Bull, J. A.; Mousseau, J. J.; Pelletier, G.; Charette A. B. Synthesis of Pyridine and Dihydropyridine Derivatives by Regio- and Stereoselective Addition to N-Activated Pyridines. Chem. Rev. 2012, 112, 2642-2713.

(7) (a) Franke, P. T.; Johansen, R. L.; Bertelsen, S.; Jørgensen, A. Organocatalytic Enantioselective One-Pot Synthesis and Application of Substituted 1,4-DihydropyridinesHantzsch Ester Analogues. Chem. Asian J. 2008, 3, 216-224. (b) Jiang, J.; Yu, J.; Sun, X.-X.; Rao, Q.-Q.; Gong, L.-Z. Organocatalytic Asymmetric Three-Component Cyclization of Cinnamaldehydes and Primary Amines with 1,3-Dicarbonyl Compounds: Straightforward Access to Enantiomerically Enriched Dihydropyridines. Angew. Chem., Int. Ed. 2008, 47, 2458-2462. (c) Yoshida, K.; Inokuma, T.; Takasu, K.; Takemoto, Y. Brønsted Acid-Thiourea Co-catalysis: Asymmetric Synthesis of Functionalized 1,4-Dihydropyridines from $\beta$-Enamino Esters and $\alpha, \beta-$ Unsaturated Aldehydes. Synlett 2010, 1865-1869. (d) Yoshida, K.; Inokuma, T.; Takasu, K.; Takemoto, Y. Catalytic Asymmetric Synthesis of Both Enantiomers of 4-Substituted 1,4-Dihydropyridines with the Use of Bifunctional Thiourea-Ammonium Salts Bearing Different Counterions. Molecules 2010, 15, 8305-8326. (e) Noole, A.; Borissova, M.; Lopp, M.; Kanger, T. Enantioselective Organocatalytic Aza-Ene-Type Domino Reaction Leading to 1,4-Dihydropyridines. J. Org. Chem. 2011, 76, 1538-1545. (f) Bertuzzi, G.; Sinisi, 
A.; Caruana, L.; Mazzanti, A.; Fochi, M. F.; Bernardi, L. Catalytic Enantioselective Addition of Indoles to Activated N-Benzylpyridinium Salts: Nucleophilic Dearomatization of Pyridines with Unusual C-4 Regioselectivity. ACS Catal. 2016, 6, 6473-6477. (g) Flanigan, D. M.; Rovis T. Enantioselective $\mathrm{N}$-heterocyclic Carbene-catalyzed Nucleophilic Dearomatization of Alkyl Pyridiniums. Chem. Sci. 2017, 8, 6566-6569. (7h) Zhu, Q.-N.; Zhang, Y.-C.; Xu, M.-M.; Sun, X.-X.; Yang, X.; Shi, F. Enantioselective Construction of Tetrahydroquinolin-5-one-Based Spirooxindole Scaffold via an Organocatalytic Asymmetric Multicomponent $[3+3]$ Cyclization. J. Org. Chem., 2016, 81, 7898-7907.

(8) Behenna, D. C.; Stoltz, B. M. The Enantioselective Tsuji Allylation. J. Am. Chem. Soc. 2004, 126, 15044-15045.

(9) Cid, J. M.; Romera, J. L.; Trabanco, A. A. Selective a-Monoallylation of Phenyl Ketones and Benzocycloalkanones Under Microwave Irradiation. Tetrahedron Lett. 2004, 45, 11331136.

(10) Austin, J. F.; MacMillan, D. W. C. Enantioselective Organocatalytic Indole Alkylations. Design of a New and Highly Effective Chiral Amine for Iminium Catalysis. J. Am. Chem. Soc. 2002, 124, 1172-1173.

(11) KHMDS must be used in THF solution. When toluene solution was used, 6 was obtained in lower yield (26\%).

(12) Trost, B.M., Xu, J.; Schmidt, T. Palladium-Catalyzed Decarboxylative Asymmetric Allylic Alkylation of Enol Carbonates. J. Am. Chem. Soc. 2009, 131, 18343-18357. 